\title{
Musculoskeletal Disorders in Agriculture: A Review from Web of Science Core Collection
}

\author{
Manuel Barneo-Alcántara ${ }^{1}$, Manuel Díaz-Pérez ${ }^{1}$,, Marta Gómez-Galán ${ }^{1,2}$, Ángel Carreño-Ortega ${ }^{1}$ (i) \\ and Ángel-Jesús Callejón-Ferre ${ }^{1,2, *(1)}$
}

1 CIMEDES Research Center (CeiA3), Department of Engineering, University of Almería, Ctra. Sacramento, s/n La Cañada, 04120 Almería, Spain; barneoas@gmail.com (M.B.-A.); madiaz@ual.es (M.D.-P.); mgg492@ual.es (M.G.-G.); acarre@ual.es (Á.C.-O.)

2 Laboratory-Observatory of Andalusian Working Conditions in the Agricultural Sector (LASA), Avda. Albert Einstein, 4. Isla de la Cartuja, 41092 Seville, Spain

* Correspondence: acallejo@ual.es; Tel.: +34-950214236

check for updates

Citation: Barneo-Alcántara, M.; Díaz-Pérez, M.; Gómez-Galán, M.; Carreño-Ortega, Á.;

Callejón-Ferre, Á.-J. Musculoskeletal Disorders in Agriculture: A Review from Web of Science Core Collection. Agronomy 2021, 11, 2017. https:// doi.org/10.3390/agronomy11102017

Academic Editor: Enrico

Borgogno Mondino

Received: 18 August 2021

Accepted: 6 October 2021

Published: 8 October 2021

Publisher's Note: MDPI stays neutral with regard to jurisdictional claims in published maps and institutional affiliations.

Copyright: (C) 2021 by the authors. Licensee MDPI, Basel, Switzerland. This article is an open access article distributed under the terms and conditions of the Creative Commons Attribution (CC BY) license (https:// creativecommons.org/licenses/by/ $4.0 /)$

\begin{abstract}
Agricultural workers suffer from many work-related illnesses. Some of the most common include musculoskeletal disorders (MSDs). These types of disorders are caused by diverse factors. This research study intends to demonstrate the worldwide concern for MSD in agriculture. The objective is to compile and recognize in detail all the available studies on musculoskeletal disorders in agriculture developed in the world and by countries in the last 26 years. The Web of Science database was used for this purpose. Two hundred and fifty-six documents were found, of which 221 were finally selected for inclusion in the study. The studies span a period from 1995 to 2020. Of these, studies that were linked to improving sustainability stood out. Most of the research of this type emanates from developed countries. The conclusions to be drawn are that few countries pay attention to this area and that preventive measures are insufficient. Mechanization and improvement in work methods and organization are methods to reduce risks.
\end{abstract}

Keywords: physical load; farmers; biomechanics; ergonomics

\section{Introduction}

The economies of countries are impacted by occupational accidents and diseases. For this reason, public administrations are constantly promoting Health and Safety at Work [1]. The objective is to achieve "the social, mental and physical well-being of the workers" through prevention. Hence, avoiding occupational risks is essential [2].

Ergonomics is defined as "the scientific discipline that deals with the interactions between human beings and other elements of a system as well as the profession that applies theory, principles, data and methods to design in order to optimize human well-being and the overall result of the system", according to the International Ergonomics Association [3].

Ergonomics seeks to make tasks as efficient as possible, eliminating negative effects for the worker, strictly using the means necessary and avoiding errors [4].

There is an interaction between sustainability and ergonomics [5] that promotes a healthy lifestyle in line with nature [6]. In addition, other authors add design to this relationship [7] and associate it with the more efficient use of raw materials and a longer useful life of the products obtained [8].

The General Assembly of the United Nations, in 2015, established 17 goals and 169 targets in relation to sustainable development. "Promote sustained, inclusive and sustainable economic growth, full and productive employment and decent work for all" is goal number eight. One of the objectives that this goal indicates is to "Protect labor rights and promote safe and secure working environments for all workers" [9]. It is very important to adopt measures to ensure the health and safety of workers, as well as to achieve suitable work environments [10]. 
"The concept of sustainable development does imply limits—not absolute limits but limitations imposed by the present state of technology and social organization on environmental resources and by the ability of the biosphere to absorb the effects of human activities" according to the General Assembly also presented in 1987 [11].

Sustainability can be likened to a triangle with three vertices (Figure 1). Quality would fall on the first, with the environment on the second and corporate social responsibility on the third (workers' rights) [6,12].

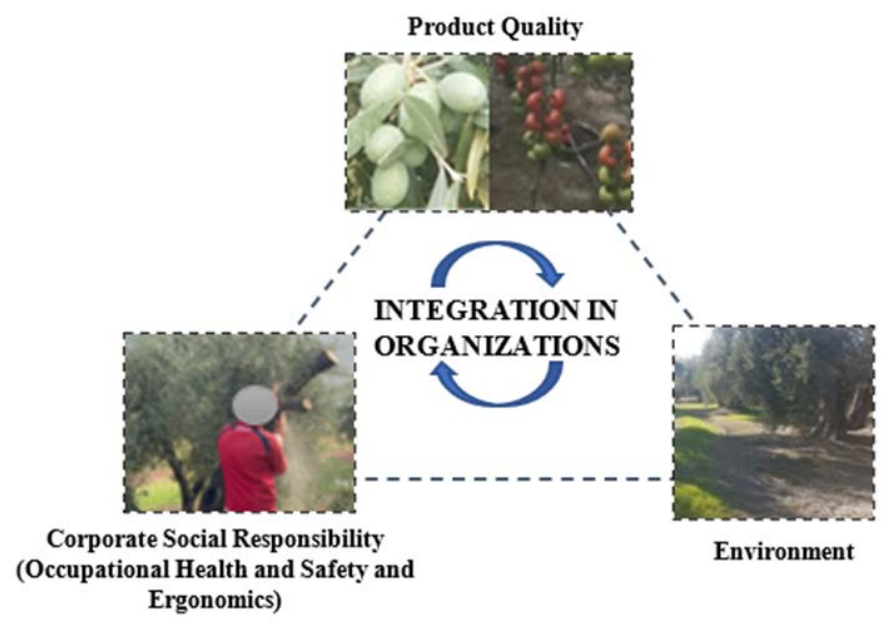

Figure 1. Triangle of sustainability [12].

Sustainability is not only based on meeting our needs in the present but also in a future life. Sustainability in the field of agriculture results in numerous improvements in human life, environment, economy, workers, use of resources, etc. [13]. Sustainable agriculture refers to the method of producing food that is in accordance with the well-being of the workers in the businesses [14].

Long ago (in the Neolithic period), when man changed from hunter/gatherer to farmer, alterations occurred in the musculoskeletal parameters of the upper extremities. Subsequent gender and age differences in agricultural tasks were attributed to this change according to some authors [15]. Society was ranked by sex [16,17]. Another author agreed that age differences were one of the causes of changes in musculoskeletal parameters but showed that there were no differences according to gender [18].

During this period, there were different points of view. A study showed that the arrival of agriculture in the Neolithic period worsened the general health of workers [19]. However, years later, another study exposed that there was a change in human health and lifestyle, but it became more sedentary with fewer health problems and, therefore, fewer musculoskeletal and psychosocial disorders [20].

Later, in the Middle Ages, musculoskeletal disorders increased due to the evolution of agricultural/livestock tasks, affecting the upper extremities, shoulders and waist; however, other congenital, degenerative and infectious pathologies were present in this period [21].

In more recent times, congenital problems have been related to phytosanitary treatments. Their incidence has been higher or lower depending on the countries and on the levels of exposure [22].

Many studies have reported on how work affects agricultural labourers. In rice cultivation and in similar tasks, musculoskeletal disorders differ between men and women [23]. In this cultivation work, other authors warn specifically of greater neck ailments in women than in men [24]. Lower extremity problems are accentuated due to the muddy crop conditions. Trips, slips [25] and unequal support [26] are frequent. Likewise, problems concerning allergies, cuts and noise have been described [21]. Therefore, new technological/ergonomic innovations were necessary to improve working conditions (in rice cultivation) [27]. 
However, this is not only the case in rice cultivation, as high-stress indexes have also been found in greenhouse workers (cherry tomato) who were assessed physiologically and biomechanically [28]. The same is true for beekeepers, where mechanization and technology have been practically ignored [29].

Work accidents of various kinds occur throughout the agricultural sector and range from those occurring on family farms, where the habitual residence is at the farm site and where the infrastructure is deficient [30], to those associated with the handling of organic remains that can cause bone diseases as a result of inhaling organic dust with microbial components [31,32].

In general, studies on occupational risk prevention in agriculture are divided into six areas: health and safety; the labour market and employment; durable agriculture; organization; agricultural policy and reform; and family farming [33].

Musculoskeletal disorders (MSDs) are one of the most relevant occupational diseases in the agricultural sector $[34,35]$. Their frequency is due to the high number of manual tasks [36].

According to the European Agency for Safety and Health at Work, MSDs are defined as "alterations suffered by body structures such as muscles, joints, tendons, ligaments, nerves, bones and the circulatory system, caused or fundamentally aggravated by work and the effects of the environment in which they take place" [37].

There are numerous methods for assessing MSDs. These differ according to the means available to the assessors-from very sophisticated methods that are dependent on sensors (infrared, ultrasound, etc.) to simple questionnaires. A classification of the most common methods has recently been described (Figure 2) [38-61].

\section{DIRECT METHODS}

HADA Move-Human [39]

Kinect System [40]

\section{INDIRECT METHODS}

Standardized Nordic Questionnaire (NMQ) [41]

Michigan Questionnaire [42]

Quick Exposure Check Questionnaire (QEC) [43]

Keyserling Questionnaire [44]

\section{SEMIDIRECT METHODS}

Key Indicator Method (KIM) [45]

National Institute for Occupational Health and Safety [46]

Manual Handling Assessment Charts (MAC) [47]

Liberty Mutual tables [48]

National Institute of Occupational Safety and Health (the NIOSH equation) [49] Snook and Ciriello tables [50]

(RULA) [51]

(OCRA) [52]

(PLIBEL) [53]

$\mathrm{cia}(\mathrm{IBV})$ [55]
Rapid Upper Limb Assessment

Occupational Repetitive Action

Method for the identification of musculoskeletal stress factors

which may have injurious effect

Job Strain Index (JSI) [54]

Instituto de Biomecánica de Valen-

Rapid Entire Body Assessment

(REBA) [57]

Posture, Activity, Tools and

Handling (PATH) [58]

莣

Ovako Working Analysis Sys-

tem (OWAS) [59]

Video film technique for Regis-

tration and Analysis of work-

ing postures and movements

(VIRA) [60]

Corlett method [61]

Posture and Repetition Risk FactorIn-

dex [56]

Figure 2. Some examples of MSD assessment methods [38]. 
Their use and impact worldwide have been studied in several of these studies $[12,14,38,62]$. The most commonly used one has been the NMQ [14] on 259 occasions, followed by RULA [12] at 226, OWAS [38] at 166 and REBA [62] at 91 (Figure 3). One can observe that their applications are practically the same on all continents except Africa. Of the South American countries, Brazil stands out. None of these assessment methods have been applied in the former Soviet Socialist Republics. In Europe, their application is widespread, as is the case in North America, South Asia and Australia.
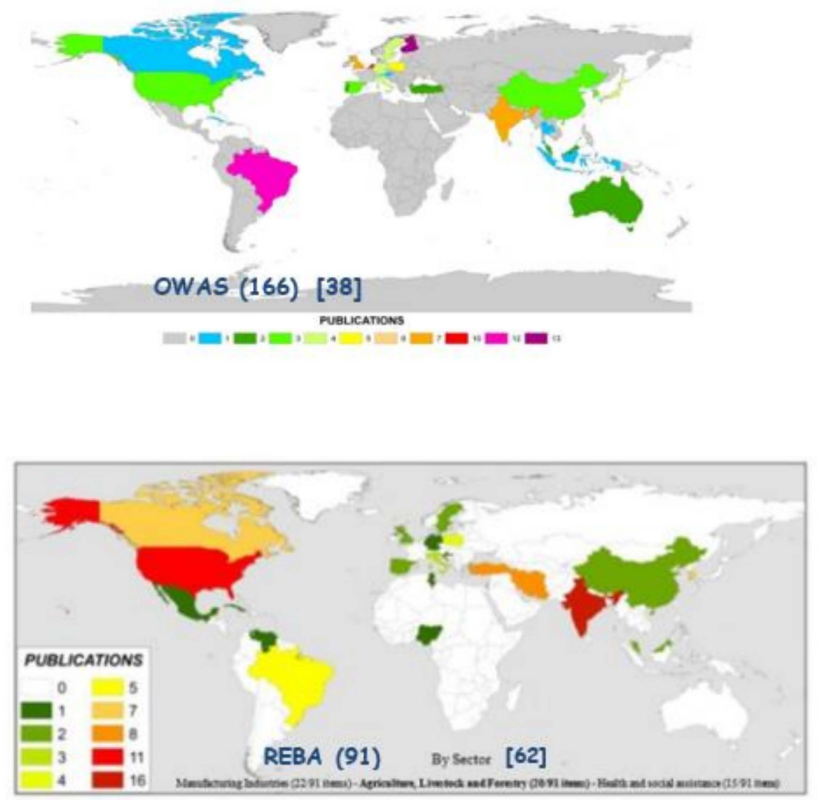
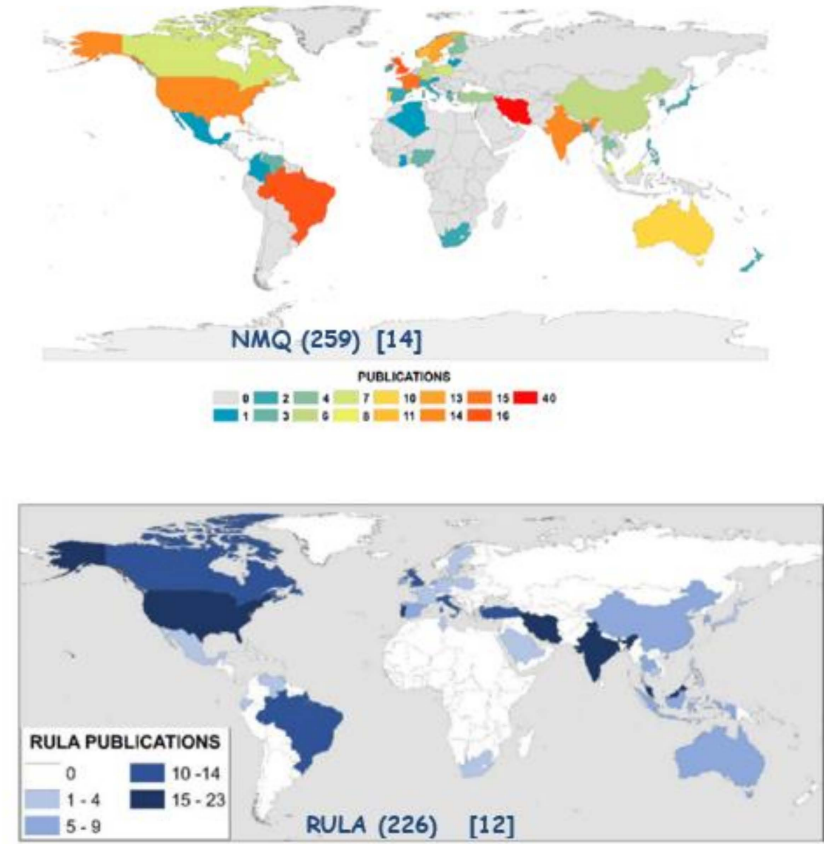

Figure 3. Use of the most significant methods [12,14,38,62].

MSDs are the result of many factors. In turn, psychosocial risks are linked to MSDs and vice versa. Musculoskeletal problems can be the consequence of stress and work rhythm [37,63-67]. This relationship has been proven in various sectors: aviation [68], computing [69], catering [70] and medicine [71,72], etc.

Rohles described all the interrelationships that affect workers in the agricultural sector. He called them "physical factors, organic factors, and adaptive factors" (Figure 4) [73].

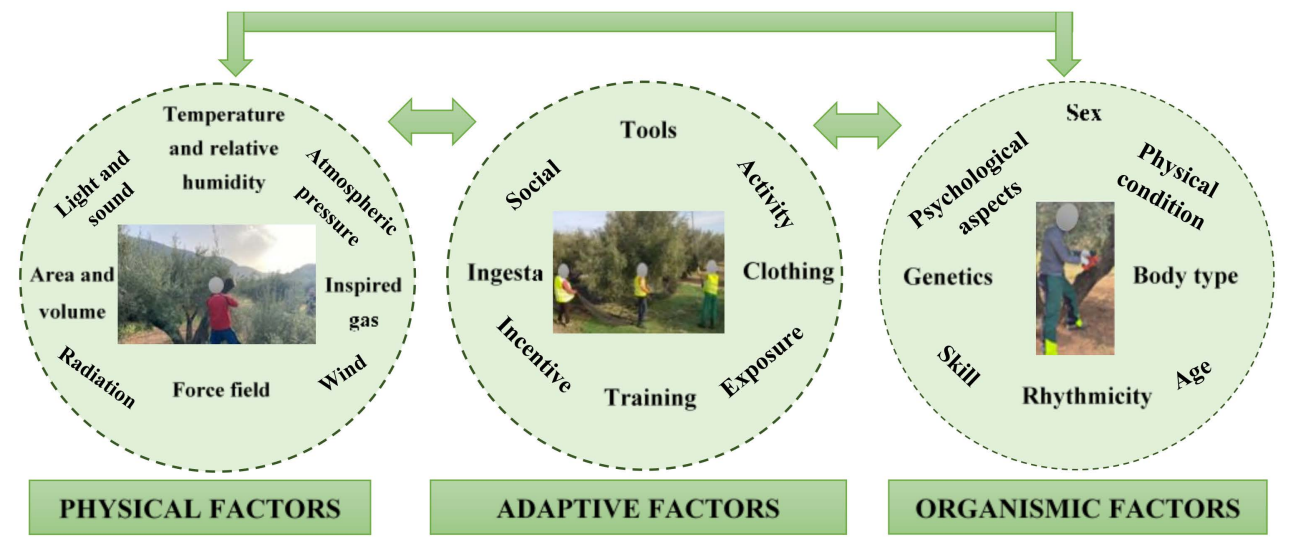

Figure 4. Relationship between physical, adaptive and organismic factors. Adapted from [73].

More recently, this relationship between the factors has been interpreted by Marras and Hancock as the interaction between two subsystems - the physical and the cognitive (Figure 5) [74]. 


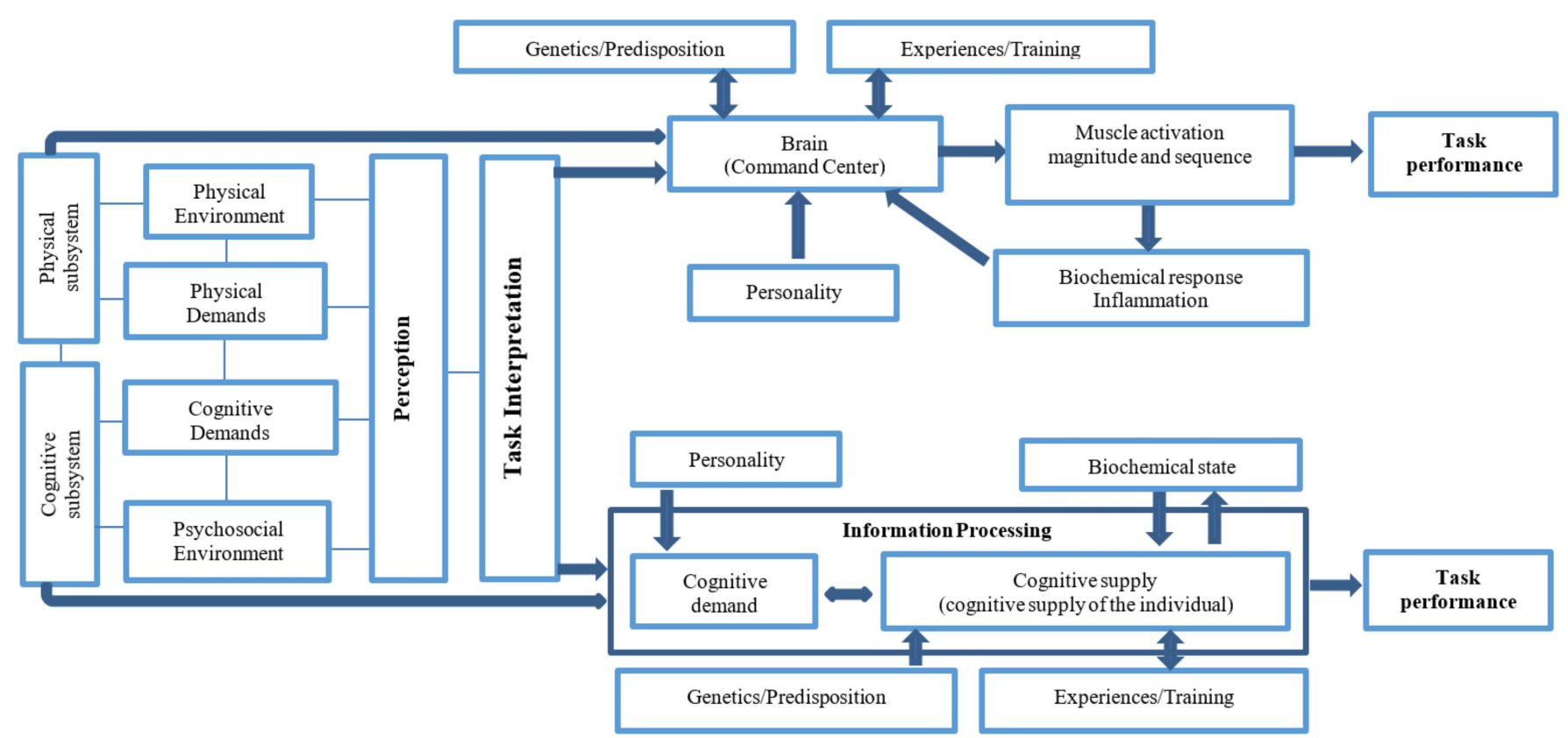

Figure 5. Interrelation between the physical and cognitive subsystems. Adapted from [74].

For this reason, each individual does not perceive, interpret or execute agricultural tasks in exactly the same manner. Personality, genetics, predisposition, training, experiences and the biochemical muscle-activation response will be fundamental factors (within the subsystems) for the final execution of tasks [74].

This study aims to demonstrate the worldwide interest concerning MSDs in the agricultural sector. The objective is to compile and recognize in detail all the available studies on musculoskeletal disorders in agriculture developed in the world and by countries in the last 26 years.

In order to achieve this objective, some specific questions should be answered:

- In which countries has MSD in agriculture been researched?

- Which studies are available related to MSD in agriculture until 2020?

- After establishing a classification, what is the number of studies in each category?

- What has been the evolution of the number of studies over time?

\section{Materials and Methods}

For information search, the Scopus, Web of Science and Google Scholar databases were considered. Finally, it was decided to use Web of Science because this database is a reference in the quality criteria of Spanish universities in engineering and applied sciences.

The "Web of Science Core Collection" was used and accessed through the website of the "Nicolás Salmerón" library of the University of Almería. The "Advanced Search" option was selected, and two words were entered using the field tag "ts = topic": "ts $=$ musculoskeletal" and "ts = agriculture". The choice of these words was decided by the authors according to the following criteria: "Musculoskeletal" was selected because English disorders of this type are usually expressed as MSDs (musculoskeletal disorders), and "Agriculture" was selected because the study focuses on this sector.

The search was carried out in all languages and for all types of documents. The time period selected was from the first year available in the database to the year in which the study was conducted (2020).

After the search, 256 documents were obtained, corresponding to the period from 1995 to 2020. Of the total obtained, six documents were removed because they were not related to the subject of the study. This initial choice was made by consulting the titles. 
Subsequently, a detailed review of the 250 selected documents was conducted. In this review, publications focused on MSD in humans with DOI were chosen, selecting a total of 245 documents.

Finally, another selection criterion was applied: studies related to MSD in humans and agriculture. In this manner, 221 documents (included in this study) were finally selected, corresponding to the years 1995-2020. Finally, the information was classified according to different criteria.

The information search procedure was conducted as follows (Figure 6).

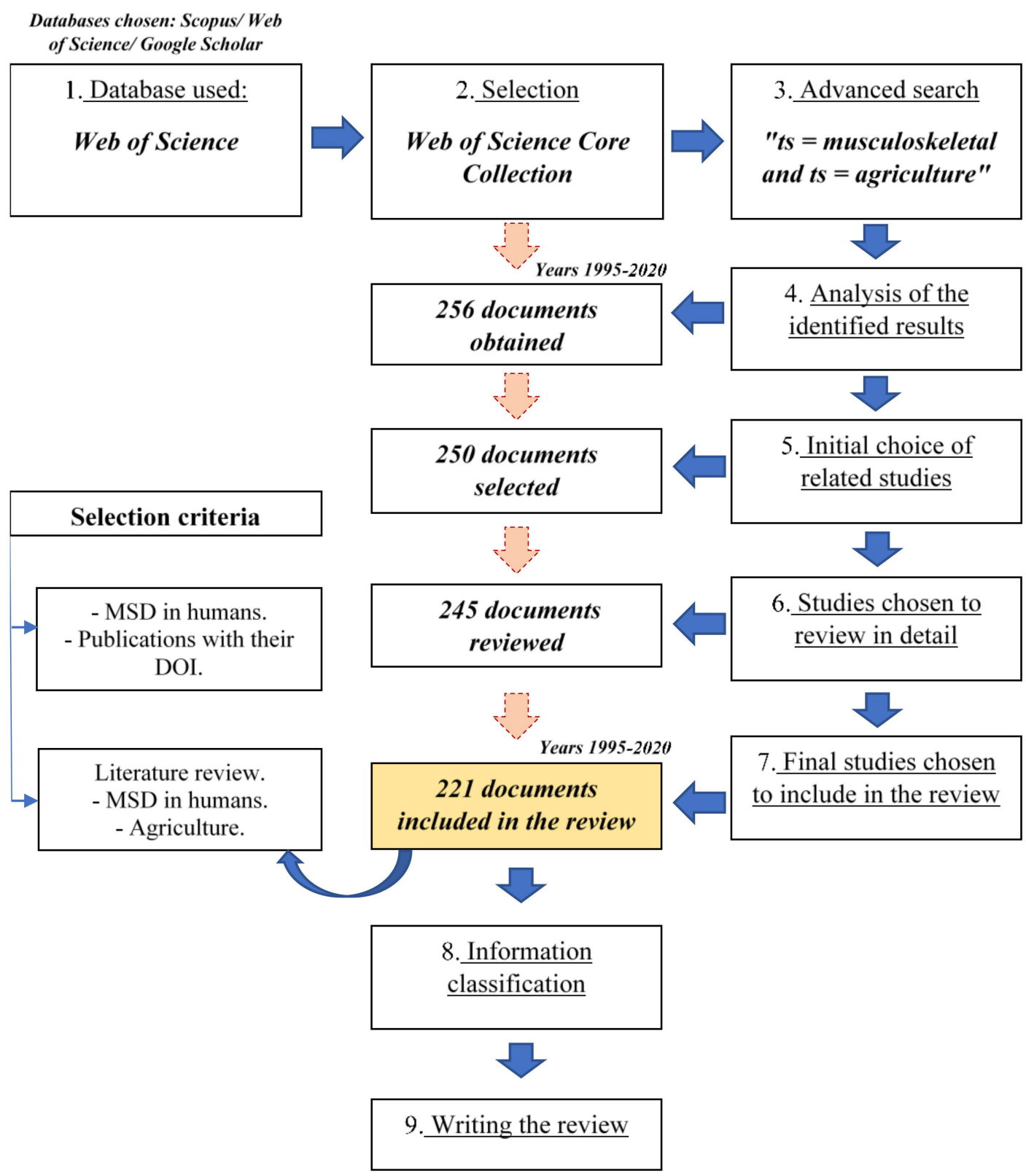

Figure 6. Search procedure.

\section{Results and Discussion}

\subsection{MSD Studies in Agriculture}

Figure 7 is shown in order to answer the first question posed in the objective: "In which countries has MSD in agriculture been researched?". 


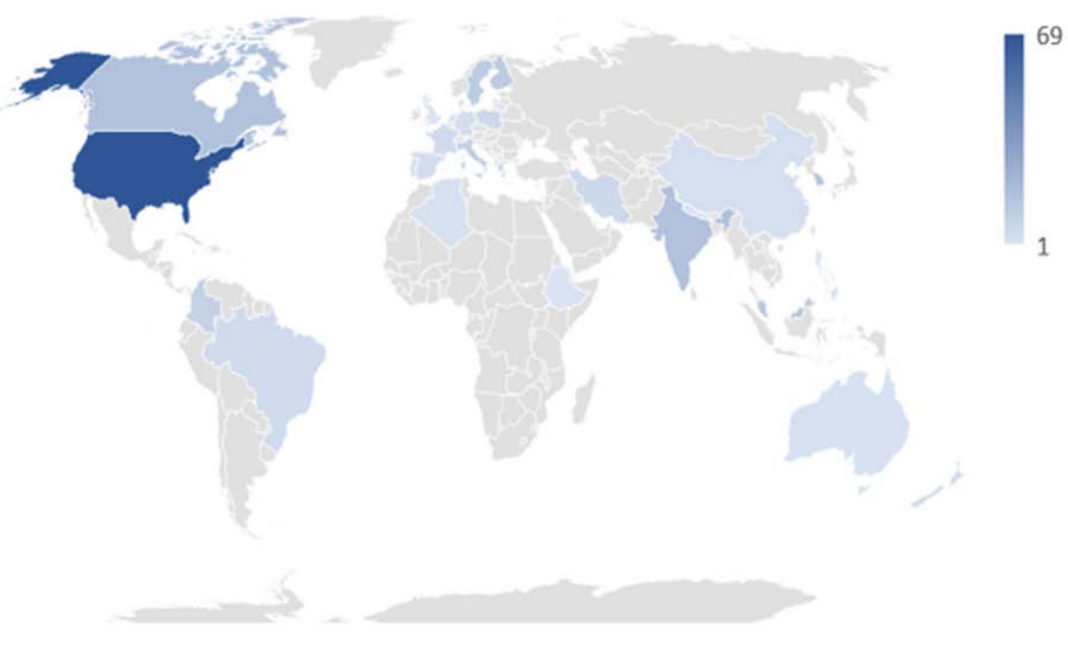

Figure 7. Studies on MSD in agriculture by country (1995-2020).

The figure shows in a general manner the countries in which the prevention of musculoskeletal disorders has become important in world agriculture from 1995 to 2020. The countries represented in blue are those in which a study has been carried out on this topic. If the blue color is darker, then it represents a greater number of studies in that country, the maximum frequency being 69 as observed in the legend. It can be observed that there are still many places where this problem is not considered.

Studies of musculoskeletal disorders in agriculture are usually performed in developed and not developing countries. The independent maps for each case are also shown. The largest number of studies has been carried out in the countries with darker colors (Figures 8 and 9).

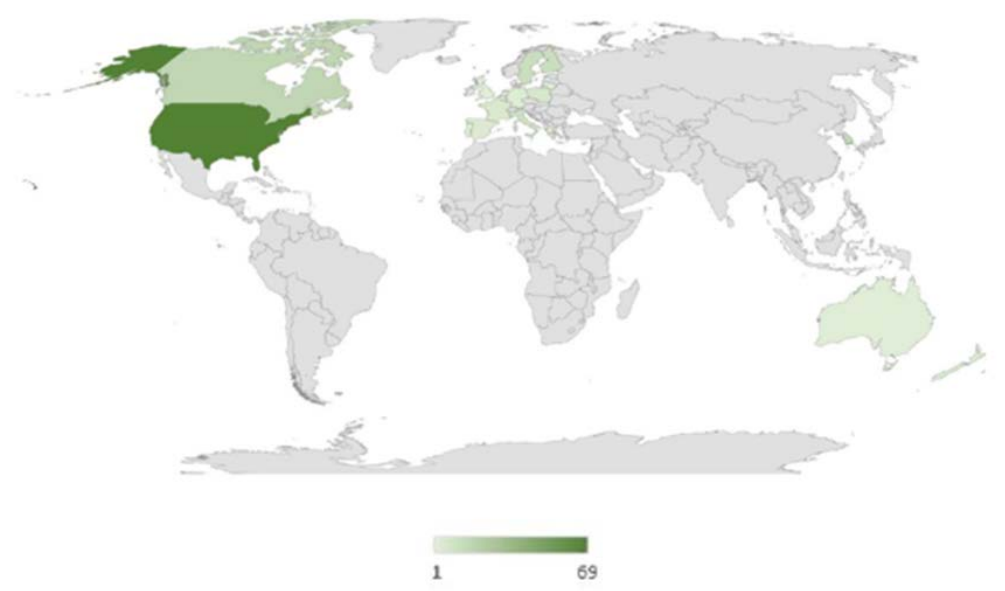

Figure 8. Studies on MSD in agriculture (1995-2020). Developed countries. 


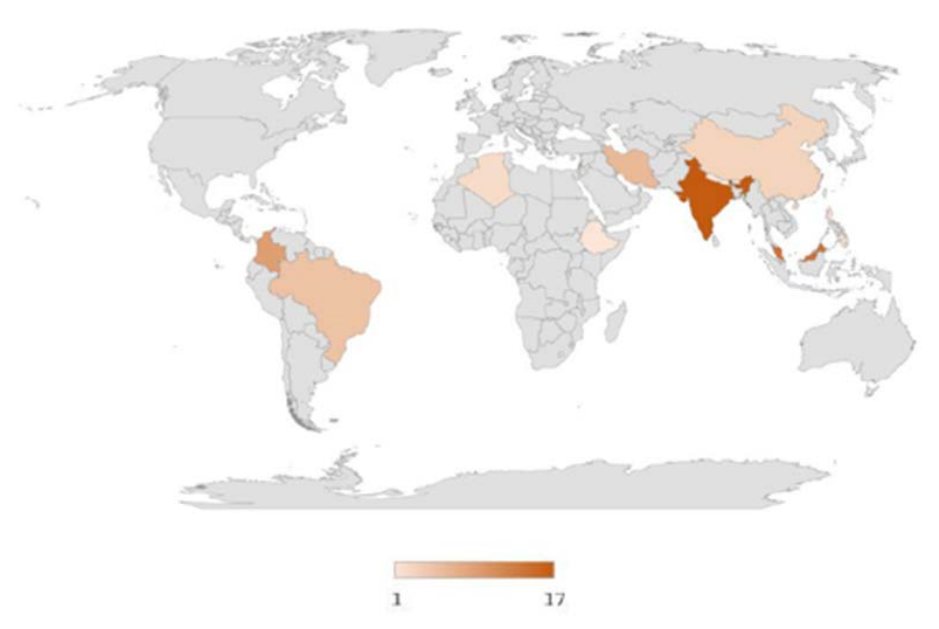

Figure 9. Studies on MSD in agriculture (1995-2020). Developing countries.

Tables A1-A19 (Appendix A) detail the studies of musculoskeletal disorders in agriculture carried out in each of the countries. In this manner, the second question of the objective is also answered: which studies are available related to MSD in agriculture until 2020?

In these tables, the studies are classified according to certain categories. These categories were decided by the authors after reviewing all available documents. The studies were grouped according to the common and most used criteria in all those analyzed in order to establish a relationship between them.

The classification by country was carried out to have an overview of the difference in research on the subject in developed and developing countries. It can be an indicator of the improvement of worker's lives. The countries that already carry out studies in this field are making progress, while the others are in a precarious situation.

The most important results obtained from these Tables A1-A19 are summarized below.

Regarding age category, it is observed that workers who are minors suffer from musculoskeletal disorders in both developed (USA, Finland and Sweden) and developing countries (India and Nepal) [22,75-83]. In older workers, these disorders are directly related to low levels of training, inexperience and poor working conditions (Thailand, the Solomon Islands, Italy and the USA) [84-87]. More specifically, in people over 45 years of age, a high frequency of MSDs associated with back, shoulder and extremity pain has been observed. All of this reduces the productivity of the agricultural sector (Thailand, Trinidad and Tobago, India, South Korea, France, Canada and Finland) [36,84,88-96].

In addition to the relationship with age, the body areas most affected in workers are obtained according to the task they performed.

Neck-related MSDs are frequent in dairy farms with quad drivers in orchards and in palm tree plantations (Malaysia, Thailand, USA and Canada) [97-102].

MSDs related to the back, spine and lower back are associated with agricultural holdings. Common ailments in the agricultural sector are considered (China, Brazil, India, Malaysia, Iran, Finland, USA, South Korea, Canada, Singapore and Greece) [100-124].

Hip-related MSDs have not been investigated in developing countries. However, in developed countries, it has been shown that there is a relationship of this disease with the driving tractors and agricultural machinery for a long period of time (South Korea and USA) $[114,116]$.

MSDs in the upper extremities are related to milking tasks, machinery vibrations and fruit harvesting (Colombia, Thailand, Finland, the United Kingdom, USA, Sweden, Italy, Poland, Canada, the Netherlands and Portugal) [125-141].

In the lower extremities, MSDs appear in traditional cultivation and slopes. Rice cultivation stands out, above all, due to slipping (Thailand, Malaysia and South Korea) [25,91,142,143]. 
In general, MSD in agriculture affects several parts of the body at the same time (Malaysia, India, Costa Rica, Panama, Guatemala, El Salvador, Nicaragua, Canada and Italy) $[90,97,144-149]$. Furthermore, MSDs usually number greater in livestock farms than in other agricultural activities (Greece, USA, South Korea, Sweden, Germany, Sweden, Poland and Canada) $[83,95,135,137,150-164]$.

On the other hand, MSDs are directly related to gender anthropometry. Women not only perform agricultural work but household chores also fall to them (China, India, Iran, Ethiopia, Spain, France, Sweden, Poland, Finland, Germany, Canada and Italy) $[23,24,36,80,83,103,165-174]$.

Migrants or immigrants are the weakest link in the development of agricultural tasks (women have a higher prevalence of MSDs than men). MSDs in this population group are high because they occupy the least qualified positions and have less access to preventive measures (China, Thailand and USA) [99,116,175-178]. Other important causes are the obstacles they encounter with language and culture, in addition to the lack of training on safety and health at work and the performance of demanding jobs on occasions [179-181]. Some authors have focused on breaking down the barriers to which migrant workers in the agricultural sector are exposed by carrying out studies to promote their safety and health in several countries $[182,183]$.

Finally, the available studies also refer to everything that includes the prevention of these risk and the consequences they cause.

Health systems are different in each country. The differences in the treatment of occupational ailments distort occupational risk prevention systems (India, Australia, Finland, Italy, South Korea, USA, France, Canada and the Netherlands) [81,141,175,184-199]. Preventive measures, the type of crop and the permissiveness of the authorities are factors that affect this distortion (USA and Europe) $[95,147,200]$.

Occupational health and safety awareness to prevent MSDs exist today, but sufficient preventive measures are not adopted. Furthermore, many business owners and authorities are not particularly interested in applying them (India, Malaysia, Brazil, USA, South Korea, New Zealand and Israel) [91,144,201-208].

Mechanization, technologically adapted tools, low-vibration machinery and the use of exoskeletons prevent MSDs in agricultural workers (India, Colombia, Malaysia, USA, Canada, Lithuania and New Zealand) [28,209-220]. In turn, the use of artificial intelligence, sensors and automation reduce MSDs (the Philippines, Sweden, Finland, Italy and USA) [221-225]. In contrast, traditional cultivation with low levels of mechanization usually present MSD in the upper extremities (India, Brazil, Algeria, USA and South Korea) $[36,95,124,226-228]$. The same occurs in organic or alternative agriculture where MSDs are more prevalent due to the use of more traditional farming techniques (Thailand and USA) $[229,230]$.

The prevention of MSDs and, consequently, the improvement in working conditions render agricultural operations (including livestock, fishing and forestry) more sustainable (India, Brazil, Colombia, Malaysia, Trinidad and Tobago, Iran, Thailand, Algeria, the Philippines, Finland, USA, the Netherlands, Germany, South Korea, Belgium, Portugal, Canada, Italy, France, Sweden, Spain, Poland and Greece) $[24,58,87,89,104,107,110,111,114$, $118,121,124,126,127,140,142,146,148,159,175,184,194,201,209,226,231-274]$.

\subsection{Classification of the Findings}

\subsubsection{Number of Studies According to the Classification}

The third question that results in the objective of this study is the following: After establishing a classification, what is the number of studies in each category? To answer this question, Figure 10 is used. It presents the number of studies in each of the fields that were used for the classification of Tables A1-A19 (Appendix A). A differentiation has been made between developing and developed countries. According to the United Nations (UN), there are a total of 193 countries in the world [275]. However, Figures 7-9 show that very few of them have carried out studies on MSD in agriculture. 

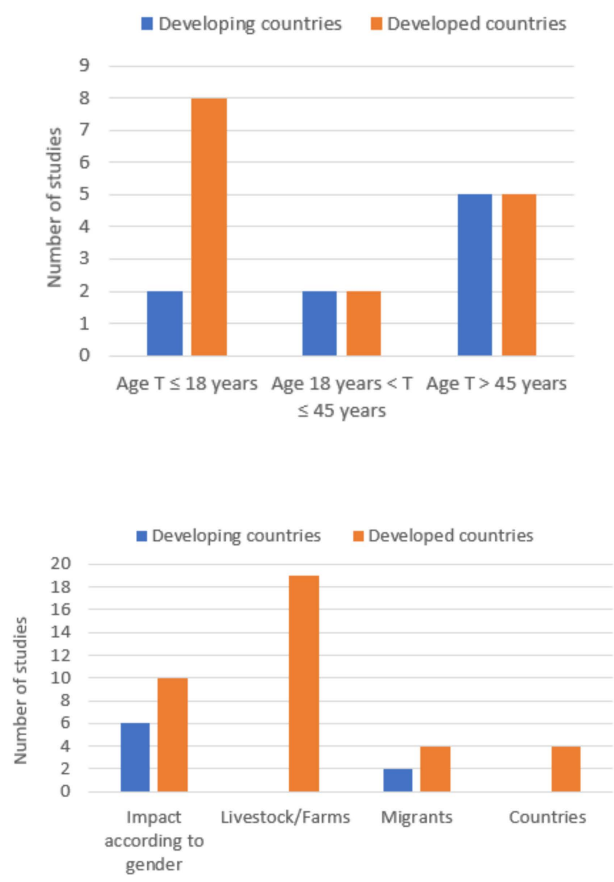
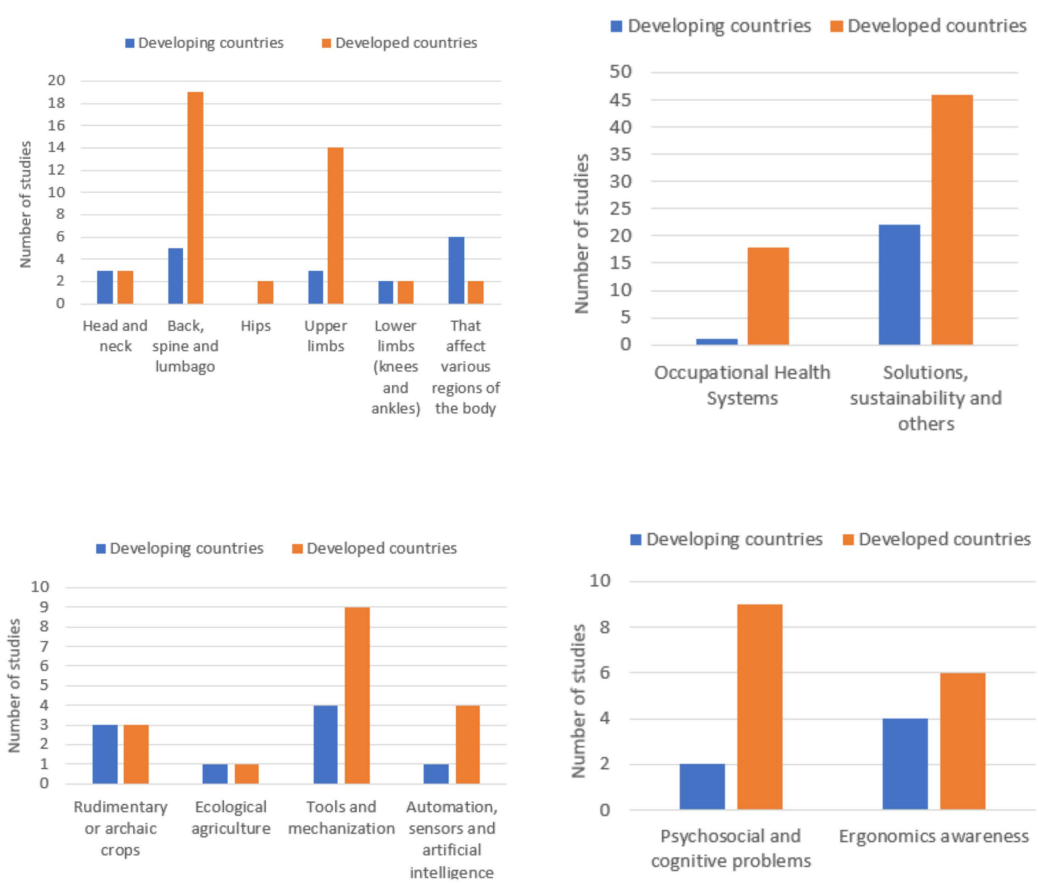

Figure 10. Number of studies according to Tables A1-A19 classification.

The number of studies carried out in developed countries is higher in almost all the fields used for classification. Only in six of these countries (age 18 years $<\mathrm{T} \leq 45$ years and age $\mathrm{T}>45$ years; head and neck, lower extremities (knees and ankles), rudimentary or traditional cultivation and organic farming) performed the same number of research studies existing in developing countries (Figure 10).

The total number of papers published on developing countries is 74 . This may indicate improved working conditions in these countries. In developed countries, the number is 190. In total, there are 264 research studies. However, as indicated in Section 2 "Material and Methods", the number of documents included in the review was 221 . The difference in the number of studies results because some of them are included in both developed and developing countries since their content is related to both cases, such as the study carried out by Taylor-Gjevre et al. [148] (see Tables A1-A19). Given the relevance of each study, these can be classified into two or more categories at the same time. Therefore, the number of studies is 221 , but some of them have been counted in more than one of the established fields.

The categories in Figure 10 were decided by the authors (Section 3.1. MSD studies in agriculture). However, the categories of the Web of Science Core Collection database to which the studies belong were also reviewed.

The category that stands out more than the others is "Public, Environmental and Occupational Health" with 111 published studies. This is followed by "Engineering, Industrial; Ergonomics" with 15, "Engineering, Industrial; Ergonomics; Psychology, Applied" with 11 and "Environmental Sciences; Public, Environmental and Occupational Health" with 10. The remaining 74 studies corresponded to other WoS categories.

\subsubsection{Number of Studies According to the Year of Publication}

The last question posed in the objective is the following: What has been the evolution of the number of studies over time? Figure 11 shows the number of studies that were published in each year. 


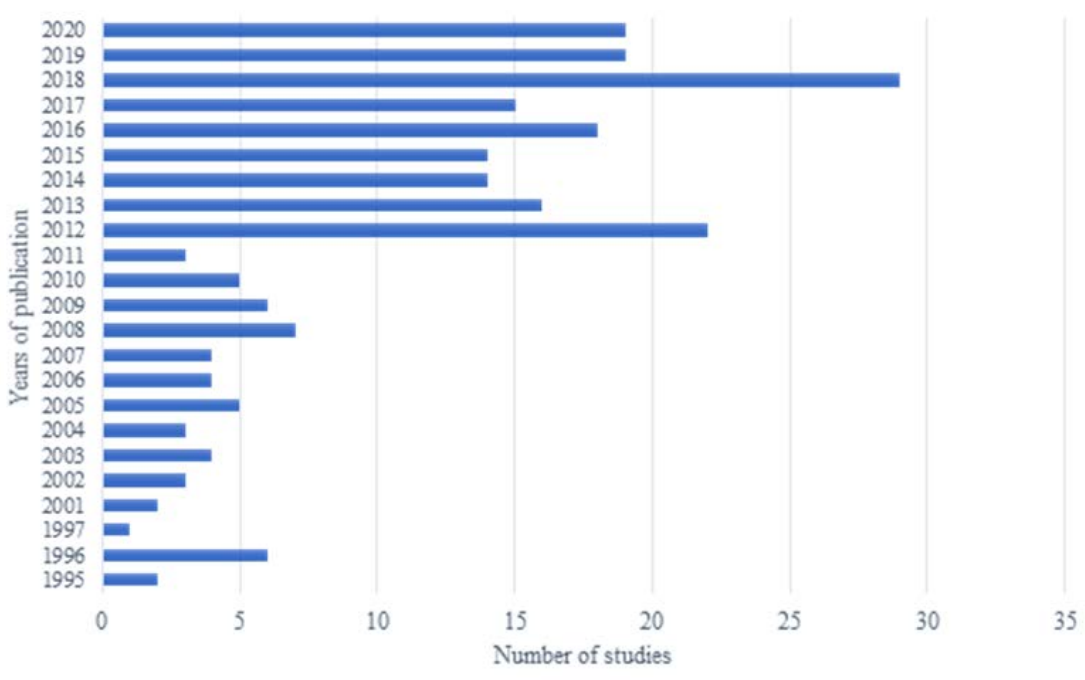

Figure 11. Number of studies identified in the period 1995-2000 concerning MSDs in agriculture (according to the year of publication).

As indicated, the studies included in this research were published between 1995 and 2020. The largest number of studies (29) was published in 2018. This is followed by 2012, with a total of 22 studies.

The two most recent years (2019 and 2020) are characterized by the same number of studies (19), showing a significant decrease compared to the previous year.

In 1997, practically no research was conducted in this field of knowledge, with only one study available. From 1998 to 2000, this topic was not studied at all (Figure 11).

This issue should continue to be important in the coming years in terms of studying measures to be applied to prevent these disorders in workers. Although several studies have been conducted in recent years, there are many activities and tasks that should be analyzed.

\subsection{Study Limitations}

The information search was carried out only in the Web of Science Core Collection. No other databases were used. In addition, the search used two words: "musculoskeletal" and "agriculture". Perhaps, some studies have not been considered by the search method used here.

On the other hand, the classification of studies by categories has been performed according to the criteria of the authors, so there are other valid classifications for this information.

\subsection{Utility and Future Studies}

This study allows researchers who focus on the prevention of occupational hazards to understand how the field of musculoskeletal disorders is in the agricultural sector. It is possible to identify the activities that have been researched so far and those that need to be studied. Since the number of people engaged in agriculture is very high, information is still needed to prevent harmful consequences for workers. The following future research directions are proposed:

- Analyze new task in the field of agriculture and new crops that have not been studied in order to observe if workers are exposed to MSD;

- Investigate new preventive and corrective measures for farmers who perform hard work that causes these disorders; 
- From the problems detected in available studies, create new equipment and tools that allow tasks to be carried out ergonomically;

- Study musculoskeletal disorders in workers in other sectors.

\section{Conclusions}

The number of available studies in the agriculture field over the years in question is not very high considering the importance of MSD on the health of agricultural workers. Some of these studies have concluded that the preventive measures adopted in this sector are insufficient.

This indicated that there is knowledge about musculoskeletal disorders, but there are some places that still have no interest in carrying out actions related to the safety and health of workers.

All countries should adopt prevention awareness regarding these types of disorders. Mechanization and new technologies are shown to have helped reduce these work-related disorders but might result in a decline in sustainable agricultural systems. Other methods to reduce MSDs have also been identified, such as training workers in ergonomics, performing multi-person tasks, encouraging breaks, alternating postures, etc. That is, the improvement of work and organizational processes.

The data from this study (with limitations) expose the need for new studies that propose preventive and corrective measures, detect risks and protect workers.

In addition, sustainability is also affected, since the fact that workers are not safe and healthy influences this field, as shown in Figure 1. One of the vertices of the triangle was the safety and health of workers; thus, if its importance is ignored, the balance of sustainability will be broken. It is essential that it is fulfilled for a better quality of life.

Author Contributions: Conceptualization, M.B.-A., M.D.-P., M.G.-G., Á.C.-O. and Á.-J.C.-F.; methodology, M.B.-A., M.D.-P., M.G.-G., Á.C.-O. and Á.-J.C.-F.; software, M.B.-A., M.D.-P., M.G.-G., Á.C.-O. and Á.-J.C.-F.; validation, M.B.-A., M.D.-P., M.G.-G., Á.C.-O. and Á.-J.C.-F.; formal analysis, M.B.-A., M.D.-P., M.G.-G., Á.C.-O. and Á.-J.C.-F.; investigation, M.B.-A., M.D.-P., M.G.-G., Á.C.-O. and Á.J.C.-F.; resources, M.B.-A., M.D.-P., M.G.-G., Á.C.-O. and Á.-J.C.-F.; data curation, M.B.-A., M.D.-P., M.G.-G., Á.C.-O. and Á.-J.C.-F.; writing-original draft preparation, M.B.-A., M.D.-P., M.G.-G., Á.C.-O. and Á.-J.C.-F.; writing—review and editing, M.B.-A., M.D.-P., M.G.-G., Á.C.-O. and Á.-J.C.F.; visualization, M.B.-A., M.D.-P., M.G.-G., Á.C.-O. and Á.-J.C.-F.; supervision, M.B.-A., M.D.-P., M.G.-G., Á.C.-O. and Á.-J.C.-F.; project administration, M.B.-A., M.D.-P., M.G.-G., Á.C.-O. and Á.J.C.-F.; funding acquisition, Á.-J.C.-F. All authors have read and agreed to the published version of the manuscript.

Funding: This research was funded by Laboratory-Observatory of Andalusian Working Conditions in the Agricultural Sector (LASA), numbers 301097 and 401487.

Institutional Review Board Statement: Not applicable.

Informed Consent Statement: Not applicable.

Acknowledgments: We gratefully acknowledge the support given by the Laboratory-Observatory of Andalusian Working Conditions in the Agricultural Sector (LASA; CG 301097 and 401487) and the Own Research Plan of the University of Almería.

Conflicts of Interest: The authors declare no conflict of interest. 


\section{Appendix A. Studies of Musculoskeletal Disorders in Agriculture Arranged by Categories}

Table A1. MSD research in agriculture (1995-2020). Category: Age.

\begin{tabular}{|c|c|c|c|}
\hline \multicolumn{4}{|c|}{ Age (T) } \\
\hline & $\mathrm{T} \leq 18$ Years & 18 Years $<\mathrm{T} \leq 45$ Years & $\mathrm{T}>45$ Years \\
\hline Developing countries $^{1}$ & $\begin{array}{c}\text { Potato cultivation assessment in India } \\
\text { using REBA and OWAS [75]. } \\
\text { Delayed diagnosis and treatment can } \\
\text { complicate treatment and decrease the } \\
\text { quality of life (Nepal) [76]. }\end{array}$ & $\begin{array}{c}\text { Less experience increases risks } \\
\text { (Thailand) [84]. } \\
\text { Greater age and lower education } \\
\text { levels pose a higher risk (the Solomon } \\
\text { Islands) [85]. }\end{array}$ & $\begin{array}{l}\text { The older the worker, the greater the } \\
\text { lower extremity MSD (Thailand) [84]. } \\
\text { In vegetable cultivation, generalized } \\
\text { MSD was detected in the } 100 \text { workers } \\
\text { assessed (Trinidad and Tobago) [89]. } \\
\text { Using the Standardized Nordic } \\
\text { Questionnaire (NMQ), MSDs were } \\
\text { found to be associated with the upper } \\
\text { parts of the body in a sample of } 138 \\
\text { agricultural workers (India) [36]. } \\
\text { Greater shoulder and neck problems } \\
\text { caused by manual tasks were found } \\
\text { using the RULA method (India) [90]. } \\
\text { The older the worker, the more } \\
\text { necessary the training in Occupational } \\
\text { Risk Prevention (Thailand) [88]. }\end{array}$ \\
\hline
\end{tabular}

Congenital defects due to phytosanitary products (USA) [22]. Small livestock farms (<20 ha) and low levels of education present a higher incidence of physical and psychosocial problems than do large livestock concerns (Finland) [77]. They represent $8 \%$ (USA) of the general population and account for $40 \%$ of work-related deaths among minors [78]

They perform the same tasks as adults and sometimes even more dangerous tasks (USA) [79].

They perform physically demanding jobs that put them at risk (Finland) [80].

High injury rates have been detected

Developed countries ${ }^{2}$

in temporary immigrant workers 87

workers interviewed in North

Carolina-USA). Affected $26.4 \%$

between 10 and 13 years, $39.1 \%$

between 14 and 15 years and $34.5 \%$

between 16 and 17 years. A

proportion of $78.2 \%$ were born in the

USA. They were paid around $55 \%$ of

the salary. Personal protective

equipment (PPE) was hardly used.

Only $5.7 \%$ had received training in

handling/applying phytosanitary products [81].

There is evidence of a direct

relationship between pesticides and

birth deformations (USA) [82].

Dairy producers present ailments in

the shoulders, elbows, lower back and feet (Sweden) [83].
Young people are more eager to receive training. The older and less educated the worker is, the less the consideration given to risk prevention measures (Italy) [86]

Adverse effects such as heat stroke, dermatitis and MSD (USA) [87].
Older workers, manual tasks and small farms present greater risks (South Korea) [91].

There is no significant evidence that the older the worker, the greater the risk of MSD in agriculture (South Korea) [92]

The consequences of agricultural work in retired workers were analysed using a multidisciplinary approach

(physical, psychosocial and

biochemical) in France [93].

There is a greater likelihood of chronic back disorders in less educated

workers in rural areas (sample of 350 agricultural workers and 11,251 non-agricultural workers-national survey) (Canada) [94]

Farms with more experienced workers and poor ergonomic factors favour. increased risks (South Korea) [95].

The greatest work capacity is found in those under 64 years of age (2169 Finnish workers assessed) [96]

\footnotetext{
${ }^{1}$ Developing countries in agriculture: Iran, India, China, Malaysia, Thailand, the Solomon Islands, Borneo, Nepal, Indonesia, Morocco, Tunisia, Egypt, South Africa, Algeria, Lebanon, Colombia, El Salvador, Mexico, Brazil, Trinidad and Tobago, Panama, Guatemala and Nicaragua. ${ }^{2}$ Developed countries in agriculture: The Netherlands, Germany, Italy, Spain, Finland, France, Sweden, Serbia, Denmark, Canada, the United States, Australia, South Korea, Lithuania and New Zealand.
} 
Table A2. MSD research in agriculture (1995-2020). Category: Head and neck.

\section{Head and Neck}

Using the NMQ and the rapid exposure questionnaire (QEC) to assess palm cultivation, greater ailments were observed in the neck compared to the back and shoulders (Malaysia) [97].

Developing countries ${ }^{1} \quad$ Poor work organization in oil palm cultivation is related to forced postures that affect the neck and shoulders (Malaysia) [98]. Using NMQ and RULA, fruit pickers in Thailand with more than 10 years of experience (a sample of 861 workers) were assessed. Neck problems were identified (Thailand) [99].

In macrofarms, greater ailments were detected in the neck and upper extremities (USA) [100].

Developed countries ${ }^{2}$

By performing analysis on 518 farmers, it was observed that neck pain associated with milking animals exceeded the rest of the MSDs detected (USA) [101].

The use of machinery (quads) could explain the high prevalence of neck pain in agricultural workers as a consequence of vibrations (Canada) [102].

\footnotetext{
${ }^{1}$ Developing countries in agriculture: Iran, India, China, Malaysia, Thailand, the Solomon Islands, Borneo, Nepal, Indonesia, Morocco, Tunisia, Egypt, South Africa, Algeria, Lebanon, Colombia, El Salvador, Mexico, Brazil, Trinidad and Tobago, Panama, Guatemala and Nicaragua. ${ }^{2}$ Developed countries in agriculture: The Netherlands, Germany, Italy, Spain, Finland, France, Sweden, Serbia, Denmark, Canada, the United States, Australia, South Korea, Lithuania and New Zealand.
}

Table A3. MSD research in agriculture (1995-2020). Category: Back, spine and lower back pain.

\section{Back, Spine and Lower Back Pain}

In an assessment of 13,965 workers, lumbar disorders were associated with moderate/strong physical stress and exposure to vibrations. Women and older workers are the most affected in agriculture in developing areas (China) [103].

The prevalence of chronic lumbago (lower back pain) (8.4\%) in tobacco farm workers was associated with advanced age, additional cattle rearing,

Developing intense physical effort, forced postures and psychosocial disorders (Brazil) [104].

countries ${ }^{1} \quad$ Current interventions in India are not effective in returning workers to ailment-free agriculture (India) [105].

The greatest MSD risks in rice cultivation were mainly associated with the spine. This is related to the temporary nature of the work (Malaysia) [106] Using QEC and NMQ, it was found that Iranian agricultural workers who used tools improved their ergonomic conditions compared to those who did not (Iran) [107].

The agricultural workers modified their postures when carrying out the tasks. Assessment with OWAS. They learned new work techniques and reduced their forced postures (bending over and twisting of the back) from $34 \%$ to $4 \%$ (Finland) [108].

A high MSD prevalence in corn and soybean agricultural workers. A sample of 499 workers (Kansas, USA) [109].

Worldwide research highlighting that working with a bent back is the most harmful posture (USA) [110]

Muscle tension and fatigue in the back was reduced when using safety belts during apple picking [111].

Exposure to vibrations over long periods is associated with temporary and lifelong back pain (USA) [112].

In vineyards, MSD affects $32 \%$ of men and $43.7 \%$ of women. Many agricultural workers lack health insurance or access to health care services (Oregon, USA) [113]

Agricultural jobs are directly related to osteoarthritis and lower back pain in South Korea. It was noted that the authorities show little interest in this issue [114].

There is a high incidence of MSD in agriculture along with other activities such as mining and construction (USA) [115].

The MICASA method was used to assess 759 agricultural workers. MSD was found in women if they knelt for more than $35 \mathrm{~h} /$ week (USA) [116] In mega dairy farms, casual workers have a higher MSD prevalence in the upper back (USA) [100].

In a study of 518 agricultural workers, it was found that maintaining agricultural equipment and machinery was associated with MSD in the lumbar

Developed area (33.2\%), neck/shoulder (30.8\%) and elbow/wrist/hand (21.6\%). Milking tasks were associated with shoulder pain. The handling of loads was countries $^{2}$ associated with pain in the elbow/wrist/hand (USA) [101].

In a study of 187 Canadian prairie farmers, using machinery was associated with vibration effects on the body (Canada) [117]

Vineyard tasks were related to back pain (USA) [118].

Poor health checks and precarious schedules were directly related to lower back pain. The Oswestri disability index (ODI; South Korea) [119] was used.

In an assessment of 835 agricultural workers (RX), a higher incidence of lumbar MSD was detected in women and young people than in men and older people (South Korea) [120].

The load weight, age, body weight, sex and height are parameters that influence MSD to a greater or lesser extent (Singapore) [121].

Vibrations cannot be categorically related to agricultural workers operating tractors and machinery (Canada) [122].

Load handling, forced postures and repetitive movements cause cumulative and acute disorders. Other risks such as cuts, fractures, travel distance,

load weight, sex, height and mechanization are also the causes of additional problems. A sample of 49 field crop agricultural workers was assessed using sensors (direct assessment methods; USA) [123]

The most studied task was harvesting, followed by transporting, loading, pruning, planting and other common manual operations. Repetitive movements, forced postures (squatting and kneeling), individual characteristics, poor tool design and using machinery favoured higher risks (Greece) [124].

${ }^{1}$ Developing countries in agriculture: Iran, India, China, Malaysia, Thailand, the Solomon Islands, Borneo, Nepal, Indonesia, Morocco, Tunisia, Egypt, South Africa, Algeria, Lebanon, Colombia, El Salvador, Mexico, Brazil, Trinidad and Tobago, Panama, Guatemala and Nicaragua. ${ }^{2}$ Developed countries in agriculture: the Netherlands, Germany, Italy, Spain, Finland, France, Sweden, Serbia, Denmark, Canada, the United States, Australia, South Korea, Lithuania and New Zealand. 
Table A4. MSD research in agriculture (1995-2020). Category: Hips.

\begin{tabular}{ll}
\hline & \multicolumn{1}{c}{ Hips } \\
\hline Developing Countries $^{1}$ & No Studies Have been Found. \\
\hline & $\begin{array}{l}\text { Hip osteoarthritis is a common disease amongst agricultural workers. } \\
\text { There are few studies focusing on this ailment. Comprehensive } \\
\text { Developed countries }{ }^{2}\end{array}$ \\
& $\begin{array}{l}\text { approaches are needed in rural areas (South Korea) [114]. } \\
\text { Driving tractors or equipment for more than } 60 \mathrm{~h} / \text { week in men is } \\
\text { associated with hip MSD. The MICASA method was used to assess } 759 \\
\text { agricultural workers (USA) [116]. }\end{array}$ \\
\hline
\end{tabular}

\footnotetext{
${ }^{1}$ Developing countries in agriculture: Iran, India, China, Malaysia, Thailand, the Solomon Islands, Borneo, Nepal, Indonesia, Morocco, Tunisia, Egypt, South Africa, Algeria, Lebanon, Colombia, El Salvador, Mexico, Brazil, Trinidad and Tobago, Panama, Guatemala and Nicaragua. ${ }^{2}$ Developed countries in agriculture: The Netherlands, Germany, Italy, Spain, Finland, France, Sweden, Serbia, Denmark, Canada, the United States, Australia, South Korea, Lithuania and New Zealand.
}

Table A5. MSD research in agriculture (1995-2020). Category: Upper limbs.

\section{Upper Limbs}

Agricultural workers numbering 158 were assessed when performing flower classification and cutting tasks. MSD in the wrist and arm was noted. Pauses/breaks are Developing countries ${ }^{1}$ suggested during the working day (Colombia) [126]. Training of rice farmers and redesigning tools reduce injuries (Thailand) [125]. In maintenance tasks for pruning and flower-cutting tools (Colombia) [127].

Thanks to mechanization, tasks in milking parlours can be considered as having low physical loads. Assessment using direct (biological parameters) and indirect (OWAS) methods (Finland) [128].

MSDs are common amongst greenhouse tomato pickers. Assessment with NMQ. A sample of 108 workers (United Kingdom) [129].

Agricultural workers, along with workers from other production sectors, suffer from carpal tunnel syndrome, tendonitis and arthritis. These conditions can be disabling. National Health Survey (USA) [130].

Migrant parents and children. A sample of 180 families (390 people) (USA) [131]. Forced postures and repetitive movements on dairy farms together with days without breaks are associated with shoulder pathologies (USA) [132].

Despite technical advances in milking parlours, MSD still exists, especially in women. NMQ was used to assess a sample of 103 people (Sweden) [133].

Electric vibrators used in olive harvesting, along with the harvesting posture, pose a risk of upper-limb disorders (Italy) [134].

Developed countries ${ }^{2}$ Overloading and forced postures on farms generate pain and/or musculoskeletal stiffness (Poland) [135].

Forced postures and load handling in greenhouse pepper harvesting. Use of 3DMatch video (Canada) [136].

Tasks in large milking parlours. Using NMQ. A sample of 450 workers (USA) [137]. They are the second highest work-related MSD in agriculture (the Netherlands) [138]. In olive tree pruning using a chainsaw, preventive measures are recommended to alleviate MSD. The methods used were OWAS, RULA and REBA (Portugal) [139]. Semi-mechanical vibration harvesting causes fatigue and various risks in the harvesting of blueberries. They used the Borg CR10 scale, electromyography (EMG), RULA, the cumulative trauma disorder index (CTD) and NIOSH (National Institute for Occupational Health and Safety; USA) [140].

In Finland, upper extremity injuries are decreasing annually on average. Finnish Register of Occupational Diseases. An analysis of 240,000 cases during the period 1975-2013 [141].

\footnotetext{
${ }^{1}$ Developing countries in agriculture: Iran, India, China, Malaysia, Thailand, the Solomon Islands, Borneo, Nepal, Indonesia, Morocco, Tunisia, Egypt, South Africa, Algeria, Lebanon, Colombia, El Salvador, Mexico, Brazil, Trinidad and Tobago, Panama, Guatemala and Nicaragua. ${ }^{2}$ Developed countries in agriculture: The Netherlands, Germany, Italy, Spain, Finland, France, Sweden, Serbia, Denmark, Canada, the United States, Australia, South Korea, Lithuania and New Zealand.
} 
Table A6. MSD research in agriculture (1995-2020). Category: Lower limbs (knees and ankles).

\section{Lower Limbs (Knees and Ankles)}

Developing countries ${ }^{1}$

Developed countries ${ }^{2}$
In rice cultivation in Thailand. A sample of 30 agricultural workers (Thailand) [25].

Good physical and maintenance conditions for workers favour the prevention of musculoskeletal risks (Malaysia) [142].

Kneeling when weeding and harvesting on traditional South Korean farms [91].

In diverse agricultural holdings using semi-direct assessment methods. Traditional farmers. (South Korea) [143].

\footnotetext{
${ }^{1}$ Developing countries in agriculture: Iran, India, China, Malaysia, Thailand, the Solomon Islands, Borneo, Nepal, Indonesia, Morocco, Tunisia, Egypt, South Africa, Algeria, Lebanon, Colombia, El Salvador, Mexico, Brazil, Trinidad and Tobago, Panama, Guatemala and Nicaragua. ${ }^{2}$ Developed countries in agriculture: The Netherlands, Germany, Italy, Spain, Finland, France, Sweden, Serbia, Denmark, Canada, the United States, Australia, South Korea, Lithuania and New Zealand.
}

Table A7. MSD research in agriculture (1995-2020). Category: Affecting various parts of the body.

\begin{tabular}{|c|c|}
\hline \multicolumn{2}{|r|}{ Affecting Various Parts of the Body } \\
\hline Developing countries ${ }^{1}$ & $\begin{array}{l}\text { Oil palm workers. Using REBA (Malaysia) [144]. } \\
\text { In oil palm plantations, there is a high prevalence of injuries, particularly during } \\
\text { intensive manual labour and harvesting. The use of semi-direct and indirect } \\
\text { methods (Malaysia) [145]. } \\
\text { Workers suffer acute pain yet continue to work, although their productivity is } \\
\text { reduced by half (Malaysia) [146]. } \\
\text { Palm tree cultivation and harvesting tasks cause back and shoulder pain. Using } \\
\text { NMQ and QEC (Malaysia) [97]. } \\
\text { The prevalence of MSD in the neck for agricultural workers in El Salvador and } \\
\text { Nicaragua was } 47.8 \% \text { and } 45.9 \% \text {, respectively. However, back pain in } \\
\text { Panamanian and Guatemalan agricultural workers was } 12.8 \% \text { and } 14.8 \% \text {, } \\
\text { respectively. The prevalence of pain was higher in women, especially related to } \\
\text { manual tasks. A sample of } 12,024 \text { people (Costa Rica) [147]. } \\
\text { In Indian agricultural workers, generally, age was associated with MSD in all } \\
\text { parts of the body except the shoulders and neck. RULA and NMQ were used. A } \\
\text { sample of } 140 \text { workers (India) [90]. }\end{array}$ \\
\hline Developed countries $^{2}$ & $\begin{array}{l}\text { A sample of } 2473 \text { workers on various farms. Using NMQ. A general prevalence } \\
\text { of arthritis (Canada) [148]. } \\
\text { In olive cultivation, many tasks require prolonged and intense physical efforts } \\
\text { leading to potentially greater risks. The most problematic work tasks were } \\
\text { pruning and harvesting whereas fertilizing presented the lowest risk. Using } \\
\text { OCRA. A sample of } 430 \text { workers (Italy) [149]. }\end{array}$ \\
\hline
\end{tabular}

${ }^{1}$ Developing countries in agriculture: Iran, India, China, Malaysia, Thailand, the Solomon Islands, Borneo, Nepal, Indonesia, Morocco, Tunisia, Egypt, South Africa, Algeria, Lebanon, Colombia, El Salvador, Mexico, Brazil, Trinidad and Tobago, Panama, Guatemala and Nicaragua. ${ }^{2}$ Developed countries in agriculture: The Netherlands, Germany, Italy, Spain, Finland, France, Sweden, Serbia, Denmark, Canada, the United States, Australia, South Korea, Lithuania and New Zealand. 
Table A8. MSD research in agriculture (1995-2020). Category: Impact according to gender.

Impact According to Gender

Women had a higher prevalence of lower back pain than men in all age groups. A sample of 13,965 people (China) [103].

A greater risk of MSD in women who are also engaged in livestock activities (India) [165].

Female rice growers in India present more ailments due to the additional demands of housework [23].

Gender is the greatest factor influencing all parts of the upper body except the shoulders. Using NMQ (India) [36].

Developing countries ${ }^{1}$ In a sample of 370 agricultural workers (Iran; rice, vegetables and greenhouses), MSD was detected resulting from repetitive tasks and long working hours. In women, neck pain was prevalent. In rice cultivation, MSD was related to lumbar ailments. More working experience was associated with knee and neck pain. Long hours and rapid work practices were associated with back pain. Forced postures were associated with neck, back, lower-back and knee pain [24].

Households headed by men mainly had low vulnerability and high resilience (Ethiopia) [166].

Congenital malformations in children were detected in couples who are agricultural workers. A sample of 261 cases between 1993 and 1994 (Spain) [167]. In French vineyards, workers notice discomfort in their hands and upper extremities after pruning. This varies according to gender, excess weight and work intensity [168].

Women working on Swedish pig farms had more ailments than men in the upper limbs, wrists, fingers and hands (numbness) as well as reduced muscle strength. A sample of 288 workers. Using NMQ (Sweden) [169].

Finnish women carry out household and livestock tasks. They have to bear great physical loads in their work. Men, on the other hand, are more in charge of operating machinery. It is recommended that more external staff are hired to reduce the workload (Finland) [80].

Developed countries $^{2}$ On German dairy farms, MSD was observed in $94 \%$ of women. Typically, women raise their arms above their shoulders more frequently than men due to gender-specific anthropometry and workplace design. NMQ was used (Germany) [170].

In a review study, they reported that $91 \%$ of the studies had been conducted in developed countries. Furthermore, only very few deal with lower-back disorders in women (Canada) [171].

Milking systems have been redesigned in Sweden reducing the workload and therefore the risk of MSD. Women reported fewer lower-back problems [83]. In post-menopausal Polish women, low vitamin D levels were associated with MSD prevalence and pain in the neck, thoracic spine, knees, hands and wrists. Not so with the lower back, shoulders and elbows [172].

A prevalence of lower-back pain in workers with more than 10 years of experience in Italian dairy farms [173].

Carpal tunnel ailments were detected in French male agricultural workers with co-exposure to neurotoxic substances [174].

\footnotetext{
${ }^{1}$ Developing countries in agriculture: Iran, India, China, Malaysia, Thailand, the Solomon Islands, Borneo, Nepal, Indonesia, Morocco, Tunisia, Egypt, South Africa, Algeria, Lebanon, Colombia, El Salvador, Mexico, Brazil, Trinidad and Tobago, Panama, Guatemala and Nicaragua. ${ }^{2}$ Developed countries in agriculture: The Netherlands, Germany, Italy, Spain, Finland, France, Sweden, Serbia, Denmark, Canada, the United States, Australia, South Korea, Lithuania and New Zealand.
} 
Table A9. MSD research in agriculture (1995-2020). Category: Livestock/Farms.

\section{Livestock/Farms}

Developing Countries ${ }^{1} \quad$ No Studies have been Found.

MSD is presented in livestock profession. Data from 1994 to 2006 were analysed (Greece) [150]. Dairy farm injuries to the wrist, hands and fingers. Moreover, almost $13 \%$ to the head and $11 \%$ to the chest (USA) [151].

In milking parlours where the working hours are long, MSD is observed in the upper arm. The use of assessment methods (USA) [152].

Livestock jobs are associated with MSD in the neck and upper extremities. Greater ailments with increasing work experience. A sample of 16,113 workers (South Korea) [95].

Greater ailments in the shoulders and neck. Women presented a significantly higher risk. Modifying the work organization in milking parlours is necessary (Sweden and Germany) [153]. After analysing data from Swedish dairy farms (1988-2002), technical and organizational workplace modifications were recommended (personal characteristics and lifestyle; Sweden) [154].

On farms, forced postures are adopted: forward bending of the spine and head, seats without backrests and bending of the knees (Poland) [135].

MSDs in the shoulders, knees, lower back, wrists and hands were detected in Swedish dairy farms with a higher \% in women than in men. It was also reported that there was less shoulder discomfort when robotic milking systems were used. Job redesign and mechanization reduce MSD (Sweden) [83].

The herringbone and rotary milking systems were studied. Research showed that herringbone parlour milking poses a higher risk of MSD for workers than does rotary milking (Poland) [155]

Developed countries $^{2}$ The rotary milking system is less harmful to dairy workers than the herringbone and battery milking systems. A sample of 60 people and three milking systems. Use of surface electromyography (USA) [156].

The design of the milking parlour can influence the workers' muscular activity. A sample of 11 workers. Using surface electromyography (USA) [157].

The mechanization of teat washing in milking parlours reduces MSD by decreasing muscle activity. A sample of 15 people using surface electromyography (USA) [158].

The mechanization of dairy farms, in general, reduces MSD (USA) [159].

In dairy farms, musculoskeletal injuries are related to repetitive tasks, insufficient rest, forced postures (dynamic or static) and environmental conditions (USA) [137].

Animal husbandry and animal agriculture are considered dangerous professions in Poland.

Previous operations and milking present higher muscle tension and strength values (Poland) [160].

Mucking-out tasks in horse stables were studied by several authors. Working with long-handled tools and using forklifts stood out as the most deficient from an ergonomic standpoint. Improving the ergonomic design of tools is advised (Sweden) [161]. Latino migrant workers on horse ranches were assessed musculoskeletally. Blows and stomps were identified at a high frequency. A sample of 284 workers (USA) [162].

In Kentucky (USA), Latino workers on horse ranches were off work due to MSD (USA) [163]. Pig farm workers reported $92 \%$ MSD in some part of the body during the previous twelve months. In addition, $58 \%$ of workers were off work at some point in the previous twelve months. Lifting tasks (handling dead pigs), forced postures and repetitive movements should be limited. Use of indirect methods and videos (Canada) [164].

\footnotetext{
${ }^{1}$ Developing countries in agriculture: Iran, India, China, Malaysia, Thailand, the Solomon Islands, Borneo, Nepal, Indonesia, Morocco, Tunisia, Egypt, South Africa, Algeria, Lebanon, Colombia, El Salvador, Mexico, Brazil, Trinidad and Tobago, Panama, Guatemala and Nicaragua. ${ }^{2}$ Developed countries in agriculture: The Netherlands, Germany, Italy, Spain, Finland, France, Sweden, Serbia, Denmark, Canada, the United States, Australia, South Korea, Lithuania and New Zealand.
} 
Table A10. MSD research in agriculture (1995-2020). Category: Occupational Health Systems.

\section{Occupational Health Systems}

Developing countries $^{1}$

Developed countries ${ }^{2}$

India faces traditional public health issues. Multiple studies on public health systems need to be carried out [184].

On a sample of 12,627 Dutch agricultural workers (1994-2001), implementing a prevention strategy was determined to be a priority in order to protect older agricultural workers [185]. High rates of MSD were noted in Holland's protected crop and fruit sectors. The labour authorities should prioritize ergonomic interventions in agriculture [186].

Mushroom growers and livestock farmers presented more complaints to insurance companies (1998-2001) in the Netherlands (regarding problems with the back, neck, shoulders and upper extremities [187].

Risk assessment and management of physical overloading can only be carried out by people with some type of specific training (Italy) [188].

The lack of attention to safety and minimal risk awareness on the part of agricultural workers is a critical problem causing many serious injuries and fatalities. The objective of the

"Demetra" project was to ensure optimal levels of occupational health and safety (Italy) [189]. There is a relationship between MSD in agricultural workers who had previous injuries and high labour claims. Novel preventive strategies are suggested. A sample of 1013 people using surveys (South Korea) [190].

Young agricultural workers in North Carolina are sometimes not treated fairly. Their job security is limited. Novel prevention plans are necessary (USA) [81].

A multidisciplinary health surveillance system to detect those sectors most in need of preventive measures (France) [191].

Comprehensive health surveillance systems would be successful in creating and exchanging ergonomic information in the agricultural sector (Australia) [192].

An analysis of 479 scientific articles showed the moderate efficacy of prevention programmes aimed at agricultural workers (USA) [193].

Agricultural workers identified many barriers to accessing health-care services. A sample of 12 people. Workers developed self-management techniques to solve their MSD problems (Canada) [175].

Introducing short and frequent breaks can improve the workers' well-being. A sample of 98 people working in strawberry cultivation (USA) [194].

Physiotherapists present better training and treat MSD better than other occupational therapists (USA) [195].

Agricultural workers were assessed for MSD using indirect methods (2595 people). At least $85.6 \%$ of the interviewees presented ailments in some part of the body over the previous year. The lumbar area was affected in $57.7 \%$ of all cases, the shoulders in $44 \%$ and the neck in $39.6 \%$ (Canada) [196].

An assessment of Latino migrant agricultural workers in Georgia using a mobile unit identified eye problems and MSD (USA) [197].

The prevalences of MSD according to race and ethnicity are not the same in the USA. The risks may be underestimated or overestimated for this reason. Fifty states were analysed by the National Statistics Service [198].

In Australia, aquaculture workers had a high incidence of injuries and illnesses accounting for a third of health insurance claims in the country's agricultural sector [199].

According to the Finnish Registry of Occupational Diseases, preventive actions should be proposed in the mining and quarrying industrial sector in addition to the construction, manufacturing and agriculture sectors where the incidence rates of occupational diseases are higher [141].

\footnotetext{
${ }^{1}$ Developing countries in agriculture: Iran, India, China, Malaysia, Thailand, the Solomon Islands, Borneo, Nepal, Indonesia, Morocco, Tunisia, Egypt, South Africa, Algeria, Lebanon, Colombia, El Salvador, Mexico, Brazil, Trinidad and Tobago, Panama, Guatemala and Nicaragua. ${ }^{2}$ Developed countries in agriculture: the Netherlands, Germany, Italy, Spain, Finland, France, Sweden, Serbia, Denmark, Canada, the United States, Australia, South Korea, Lithuania and New Zealand.
} 
Table A11. MSD research in agriculture (1995-2020). Category: Solutions, sustainability and others.

\section{Solutions, Sustainability and Others}

The developments of human resources, specialized occupational health work groups, databases and information systems have been proposed to improve MSD in women (India) whose work is dedicated to weeding crops. A sample of 2000 women using indirect methods [184].

In slaughterhouses in Brazil, veterinarians are responsible for the prevention of occupational hazards, in addition to ensuring food safety [231].

Improvements in flower crop tasks allowed more muscle rest while they were being carried out (Colombia) [126].

Reduction in forced postures, rotation of positions, more training and less handling of loads moderately improved MSD in flower cultivation (Colombia) [232].

In India in 2009, it was necessary for the authorities to legislate on MSD and work safety. Due to the authorities' slackness, apathy and lack of awareness, workers and employers did not make it possible [201].

Holistic and comprehensive ergonomic interventions using participatory and cost-effective approaches are recommended (Malaysia) [148].

Physiotherapeutic actions on the affected body areas reduce pain intensity and improve the workers' mobility (Malaysia) [233].

Comprehensive surveillance and intervention tailored to the agricultural sector is urgently required (Malaysia) [146].

In flower cultivation in Colombia, 77 workers were assessed; forced postures and problems in handling loads were noted. Improvements were proposed that did not significantly decrease the risk of MSD [234] In Trinidad and Tobago, agricultural extension services improve the health and safety of agricultural

Developing countries ${ }^{1}$ workers and business owners with training programmes [89].

Health professionals assessing agricultural workers (tobacco) must be trained to diagnose and prevent MSD (Brazil) [104].

Implementation of preventive management plans according to socioeconomic and sociodemographic factors, together with tools that facilitate load handling, reduce MSD (Colombia) [235]. Using the OWAS method.Managing rest time, using specialized-worker teams and reducing forced postures lower the risk of MSD in apple harvesting (Iran). Using NMQ and a postural study. A panel of experts assessed a sample of 30 workers [236].

Training, good physical preparation and innovative tool design decrease the risk of MSD. A sample of 68 Malaysian workers in pineapple cultivation [142].

The maintenance of tools favours a reduction in biomechanical risks (Colombia) [127].

There is a need for preventive guidance for the agricultural sector in Thailand (Thailand) [237].

Individual, educational and scientific efforts are necessary to reduce musculoskeletal risks in the cultivation of date palms in Algeria [226].

Women (in India) working in rice cultivation were assessed using RULA and indirect methods. Training and new prevention systems were proposed [238].

Truck design must follow the ergonomic and anthropometric design principle (Philippines) [121]. In rural areas of Iran, corrective actions to improve the health and safety of agricultural workers (from MSD) are a priority. A sample of 430 villages using municipal health centres [239].

Improvements in forced postures, mechanisation and ergonomic tools were recommended (Iran). A sample of 1501 workers. Using the NMQ and QEC methods [107].

Immediate work improvements are needed in rice and vegetable crop production. A sample of 377 workers (Iran). Using RULA [24].

Ninety-seven workers were assessed using OWAS. Subsequently, they were re-educated to adopt better postures for performing agricultural tasks. A decrease in lower-back and shoulder pain was noted (Finland) [240].

The "Posture, Activity, Tools and Handling (PATH)" and OWAS methods can identify operations and Developed countries 2 tasks that are ergonomically dangerous in construction, agriculture and mining (USA) [58,59]. In Californian nurseries (USA), the most harmful tasks should be selected when implementing preventive measures [241].

Good communication between employers, ergonomists and workers favours better safety and health in agricultural tasks. A sample of 243 strawberry cultivation workers using indirect methods in the USA [242]. 
Table A11. Cont

\section{Solutions, Sustainability and Others}

The quantification of "intensity," "frequency" and "duration" to determine MSD (The Netherlands) [243].

Using belts on apple farms result in significant reductions in MSD (USA) [244].

Introducing short and frequent breaks reduces the risk of MSD in workers and improves their productivity. A sample of 66 workers in strawberry cultivation (USA) [194].

To reduce the risk of MSD, more information is needed on the risks with different agricultural tasks in different crops (Germany) [245].

To solve ergonomic problems, a participatory approach involving business owners, ergonomists and workers is necessary (USA) [110].

Belt use was shown not to interfere with worker productivity in apple picking and that it reduces the risk of MSD (USA) [111].

The design of mobile platforms for blueberry harvesting reduces the risk of MSD. Using the RULA method and electromyography (USA) [246].

Improvements in the working conditions of agricultural workers increase productivity and reduce the risks of suffering MSD (USA) [247].

In South Korea, MSDs decreased in 2004 as a result of the authorities forcing employers to implement prevention programmes [248]

The implementation of good ergonomic practices in livestock farming via the website www.agri-ergonomics.eu (accessed on 1 April 2021) improves all aspects related to MSD (Belgium) [249]. All industrial sectors in the Republic of South Korea have comprehensive health surveillance systems, except for agriculture. More research is needed to decrease the incidence of MSD in agricultural workers (USA) [250]

The incidence rate of fatal accidents in small fishing vessels is very high. There is no standard international legislation on small boat construction nor on minimum levels of accident analysis education and training for fishermen (Portugal) [251].

The portion of $50.9 \%$ of workers assessed in rural Finnish health centres had one or more musculoskeletal injuries. The results are associated with repetitive movements and forced postures on livestock farms. New prevention systems are proposed [252].

The rate of claims by Finnish dairy cattle farmers to insurance companies related to MSD is $26 \%$. A sample of 283 claims. There are agricultural workers at higher risk of occupational injuries and illnesses. More preventive training is demanded [253].

Solutions for reducing exposure to musculoskeletal risks are scarce on dairy farms. Use of direct methods (USA) [159].

The reduction in MSD in dairy farm workers was achieved through information/training actions aimed at business owners (USA) [254]

Warm-up exercises by workers prior to weeding tasks reduce MSD. A sample of 44 people (Canada) [255] The use of exoskeletons in agricultural activities demonstrated their ergonomic potential for reducing the risk of lower-back pain during agricultural tasks (bucket lifting; USA). A sample of 17 workers. Using electronic sensors [256].

The health status and sociodemographic factors of Korean farmers are directly related to MSD. Preventive actions were proposed [209].

The project for "automating musculoskeletal disorder prevention at work" by the World Health Organization and the International Ergonomics Association (WHO/IEA) simplifies the assessment of agricultural workload conditions in developing countries (Italy) [257].

Physical activity adapted and supervised by ergonomic professionals prevents lower-back pain in vineyard workers. A sample of 17 workers (France) [118].

In open-air vegetable and fruit crops, MSD can be reduced by using mechanized resources and training (Sweden) [258].

Forced postures were detected in greenhouse melon workers in Almería (Spain). Corrective measures were proposed for immediate application. Using OWAS [259].

The current time limits and vibration intensities allowed when using agricultural machinery may not protect the workers from MSDs. A sample of 18 workers. Using indirect method together with simulations (Canada) [260].

Future risk assessments are the basis of ergonomic interventions to reduce forced postures in agricultural tasks (USA). Use of PATH [261]. 
Table A11. Cont.

\section{Solutions, Sustainability and Others}

Low levels of vibrations in harvesters and unforced postures reduce MSD (USA) [262].

Olive tree backpack vibrators especially affect the upper extremities. Some do not comply with the European legislation on vibrations. Use of the "Occupational Repetitive Action (OCRA)" method. It is the employer's obligation to supply standardized equipment in addition to user manuals. A sample of 5 workers and the analysis of 3 backpack vibrating machines (Italy) [263].

Spa water between 25 and 37 degrees Celsius with a high fluoride concentration tends to improve MSDs (Sweden) [264].

The multidisciplinary collaboration of health and safety professionals, engineers, social agents and ergonomists is recommended to provide a solution to MSD in the forestry sector. A sample of 414 workers from Finland, Germany, the Netherlands, France and Spain. Statistical data from the European Agency for Safety and Health at Work (Poland) [140].

Private insurance companies cover most MSD claims related to the agricultural sector. The compensation is insufficient and does not cover the most common ailments (USA) [265].

Agricultural business owners in South Korea adopted participatory approaches with their workers, which resulted in efficiency, safety and job satisfaction benefits. A sample of 388 workers using the NMQ [266].

Occupational health care should be optimized in Canadian rural areas to control chronic lower-back pain (Canada) [267].

Using machinery at low speeds and adopting unforced postures reduce lumbar MSDs (Canada) [114].

Developed countries $^{2}$ The redesigning of tools, using machinery/tractors and newer, more technologically advanced tools (robots) along with training focused on healthy activities reduce MSDs in olive workers (Spain) [268]. Assessing physical load and the adoption of non-forced postures reduce lower-back pain in agricultural workers (Canada) [269].

It is proposed that workers cultivating zucchini in greenhouses in South-Eastern Spain (Almería) are rotated with their colleagues and that the rest periods are increased to avoid the risk of MSDs in these tasks. Using OWAS [270].

Governments and companies must improve the occupational health and safety of immigrants, providing medical cover as required. A sample of 7260 immigrant workers. A study of databases from 13 countries and 25 nationalities (USA) [175].

Prolonged sitting while operating farm machinery is one of the main contributing factors to MSD. Use of direct methods (Italy) [271].

Technology can achieve a double objective: improving the workers' quality of life and increasing profitability for employers (Canada) [272].

MSDs are mitigated by ergonomic actions, awareness of preventive culture and the prioritization of health and safety measures (Greece) [124].

The adaptation of legislation must be in line with the novel ailments detected in Italian agricultural workers. Fourteen years of MSD statistical data processing (Italy) [273].

Older Latino children who perform agricultural tasks present higher levels of MSD (USA). It is recommended that the occupational safety policies are changed [87].

${ }^{1}$ Developing countries in agriculture: Iran, India, China, Malaysia, Thailand, the Solomon Islands, Borneo, Nepal, Indonesia, Morocco, Tunisia, Egypt, South Africa, Algeria, Lebanon, Colombia, El Salvador, Mexico, Brazil, Trinidad and Tobago, Panama, Guatemala and Nicaragua. ${ }^{2}$ Developed countries in agriculture: The Netherlands, Germany, Italy, Spain, Finland, France, Sweden, Serbia, Denmark, Canada, the United States, Australia, South Korea, Lithuania and New Zealand. 
Table A12. MSD research in agriculture (1995-2020). Category: Psychosocial and cognitive problems.

\section{Psychosocial and Cognitive Problems}

It is recommended that psychosocial risk factors are investigated in oil palm workers due to their relationship with MSD. A sample of 446 workers. Using OWAS (Malaysia) [98].

Developing countries $^{1}$

Reducing problems and work stress contribute to fewer worker ailments in sectors such as industry, administration and agriculture in Taiwan. Age, education, work environment, physical condition and initiative are factors that are associated with these risks [276].

Dementia problems are related to MSDs. A sample of 1002 participants in France with a minimum of 20 years experience [93].

Current working conditions should facilitate the physical and mental well-being of agricultural workers. This would reduce MSD in future. A sample of 4088 retired agricultural workers [277].

Agricultural workers suffer less stress than workers in other sectors. This results in fewer psychological-disability pensions (Sweden). Passive jobs have a higher incidence rate. A sample of 24,543 twins between 1993 and 2008 [278] Australian agricultural workers with MSD often have associated psychosocial problems in later years [279]. Symptoms of depression and anxiety greatly impact functional limitations. A sample of 2351 agricultural workers in Developed 1990-1991 and 1405 workers in 2002-2003 (Sweden) [280].

countries $^{2}$ A study of 30 organic farmers that identified intrapersonal and behavioural factors that can increase or reduce the risk of MSD and other diseases (USA) [202].

The perception of agricultural work capacity is related to the worker's mental health. Productivity is higher if the workers have fewer psychosocial problems. A sample of 2169 people in Finland [96].

The psychosocial problems of migrant Latino onion pickers in Georgia (USA) were associated with MSD. A sample of 100 people assessed in mobile health units [197].

Greenhouses in South-Eastern Spain (Almería) do not ensure the workers' comfort and do not comply with the UNE-EN 13031-1 standard. In addition, the results directly associate the different greenhouse types and their crops with the workers' ergonomic-psychosocial conditions, proposing improvements to them [281].

\footnotetext{
${ }^{1}$ Developing countries in agriculture: Iran, India, China, Malaysia, Thailand, the Solomon Islands, Borneo, Nepal, Indonesia, Morocco, Tunisia, Egypt, South Africa, Algeria, Lebanon, Colombia, El Salvador, Mexico, Brazil, Trinidad and Tobago, Panama, Guatemala and Nicaragua. ${ }^{2}$ Developed countries in agriculture: The Netherlands, Germany, Italy, Spain, Finland, France, Sweden, Serbia, Denmark, Canada, the United States, Australia, South Korea, Lithuania and New Zealand.
}

Table A13. MSD research in agriculture (1995-2020). Category: Ergonomic awareness.

\begin{tabular}{|c|c|}
\hline & Ergonomic Awareness \\
\hline $\begin{array}{l}\text { Developing } \\
\text { countries }\end{array}$ & $\begin{array}{l}\text { In India, safety-at-work measures are urgently required. The } 2009 \text { National Occupational Health and Safety } \\
\text { Regulations do not apply to agriculture [201]. } \\
\text { Most of the oil palm cultivation workers in Malaysia are unaware of preventive measures and place their health at } \\
\text { risk. Use of REBA [144]. } \\
\text { This qualitative study of } 64 \text { women tobacco pickers on small tobacco farms in Brazil highlighted the persistence of } \\
\text { MSD. These problems would improve if the authorities adopted preventive measures and promoted sustainable } \\
\text { development [203]. } \\
\text { Studies carried out in developing countries (1985-2015) do not give importance to the prevention of occupational } \\
\text { hazards (India). A sample of } 614 \text { investigations [204]. }\end{array}$ \\
\hline $\begin{array}{l}\text { Developed } \\
\text { countries }^{2}\end{array}$ & $\begin{array}{l}\text { The adoption of preventive practices against MSD on fruit farms (USA and New Zealand) was not sufficient } \\
\text { following a } 3 \text { year information campaign targeting business owners [205]. } \\
\text { Older Korean agricultural workers do not pay attention to MSD problems on their farms nor at the health facilities } \\
\text { they attend [91]. } \\
\text { For } 3 \text { years, information on MSD preventive measures was provided to greenhouse owners in New Zealand ( } n= \\
250 \text { ) and the USA ( } n=1200) \text {. The results showed that this did not influence the preventive measures, as it only } \\
\text { increased awareness amongst the business owners [206]. } \\
\text { The dissemination of information to managers through family information channels was associated with an increase } \\
\text { in reported information requests and greater adoption and awareness of safer working practices (USA) [207]. } \\
\text { Problems regarding MSD awareness depend on the perception of risk, which is greater amongst the organic farm } \\
\text { owners ( } n=10) \text { than in their agricultural workers }(n=20) \text { (USA) [202]. } \\
\text { The tasks carried out in greenhouse pepper and tomato cultivation in Israel were analysed, finding a high risk of } \\
\text { MSDs [208]. }\end{array}$ \\
\hline
\end{tabular}

\footnotetext{
${ }^{1}$ Developing countries in agriculture: Iran, India, China, Malaysia, Thailand, the Solomon Islands, Borneo, Nepal, Indonesia, Morocco, Tunisia, Egypt, South Africa, Algeria, Lebanon, Colombia, El Salvador, Mexico, Brazil, Trinidad and Tobago, Panama, Guatemala and Nicaragua. ${ }^{2}$ Developed countries in agriculture: the Netherlands, Germany, Italy, Spain, Finland, France, Sweden, Serbia, Denmark, Canada, the United States, Australia, South Korea, Lithuania and New Zealand.
} 
Table A14. MSD research in agriculture (1995-2020). Category: Rudimentary or traditional cultivation.

\section{Rudimentary or Traditional Cultivation}

Manual and individual work in India, along with low levels of mechanization, result in a higher risk of MSDs. The ailments range from $71.4 \%$ in the lower back to $5 \%$ in the hands/wrists. The NMQ was used on a sample of 138 agricultural workers [36].

Developing countries ${ }^{1}$ In Brazil, in classic banana cultivation, it was concluded that MSDs in the neck, back, shoulders and wrists are due to repetitive movements and scant mechanization. Using direct methods and surface electromyography [227].

In date palm cultivation in Algeria, the technology is limited; therefore, traditional methods are used that involve greater risks of suffering from MSD [226].

In the USA, Latino immigrant workers experience more MSDs than other workers in the forestry, agriculture and fisheries sectors [228].

In South Korea, 16,113 agricultural workers were interviewed; the findings showed a higher risk of

Developed countries ${ }^{2}$ MSDs associated with a lack of mechanization and ergonomic measures and with advanced age [95]. The most studied task is harvesting, followed by transport, loading, pruning, planting and other ordinary manual operations. Repetitive movements, forced postures, the individual characteristics of the workers and poor tool and machinery design were highlighted as factors contributing to MSDs, which is the principal disorder in agriculture (Greece) [124].

${ }^{1}$ Developing countries in agriculture: Iran, India, China, Malaysia, Thailand, the Solomon Islands, Borneo, Nepal, Indonesia, Morocco, Tunisia, Egypt, South Africa, Algeria, Lebanon, Colombia, El Salvador, Mexico, Brazil, Trinidad and Tobago, Panama, Guatemala and Nicaragua. ${ }^{2}$ Developed countries in agriculture: The Netherlands, Germany, Italy, Spain, Finland, France, Sweden, Serbia, Denmark, Canada, the United States, Australia, South Korea, Lithuania and New Zealand.

Table A15. MSD research in agriculture (1995-2020). Category: Migrants.

\begin{tabular}{|c|c|}
\hline & Migrants \\
\hline Developing countries ${ }^{1}$ & $\begin{array}{l}\text { In Hmong, China, non-mechanized agricultural activities carried out without personal protective } \\
\text { equipment increase the risks of MSD, resulting sometimes even in death from other associated risks. } \\
\text { A sample of } 36 \text { observations from } 9 \text { agricultural holdings [176]. } \\
\text { From a sample of } 861 \text { migrant fruit pickers in Thailand, using the NMQ and RULA, it was concluded } \\
\text { that task-related health conditions should be monitored [99]. }\end{array}$ \\
\hline Developed countries $^{2}$ & $\begin{array}{l}\text { It was observed that Latino migrant male workers occupy low-skilled work positions and suffer from } \\
\text { the common diseases and chronic pain (MSD) associated with older people and females (USA). A } \\
\text { sample of } 759 \text { workers [116]. } \\
\text { The data on Latino immigrants in North-Eastern USA indicate } 1260 \text { MSD cases /year. Sprains account } \\
\text { for } 56 \% \text { of these and overloading } 21.5 \% \text {. There is a higher incidence of MSDs in fruit crop workers } \\
\text { than those working with horticultural crops. Workers requested compensation in } 2.8 \% \text { of the } \\
\text { cases [177]. } \\
\text { A proportion of } 79 \% \text { of the workers suffered pain or discomfort of some kind. Shoulder pain ( } 31 \%) \\
\text { was characteristic in all workers, while back pain (66\%) was more associated with workers that had } \\
\text { more than } 5 \text { years experience. A sample of } 120 \text { Latino immigrant workers (USA) [178]. } \\
\text { After identifying } 1218 \text { studies and systematically reviewing } 36 \text { of them which dealt with immigrant } \\
\text { workers and MSD, it was concluded that there is a high risk of MSD and occupational health } \\
\text { problems in this group of workers (USA) [175]. }\end{array}$ \\
\hline
\end{tabular}

${ }^{1}$ Developing countries in agriculture: Iran, India, China, Malaysia, Thailand, the Solomon Islands, Borneo, Nepal, Indonesia, Morocco, Tunisia, Egypt, South Africa, Algeria, Lebanon, Colombia, El Salvador, Mexico, Brazil, Trinidad and Tobago, Panama, Guatemala and Nicaragua. ${ }^{2}$ Developed countries in agriculture: The Netherlands, Germany, Italy, Spain, Finland, France, Sweden, Serbia, Denmark, Canada, the United States, Australia, South Korea, Lithuania and New Zealand. 
Table A16. MSD research in agriculture (1995-2020). Category: Countries.

\section{Countries}

Developing countries ${ }^{1} \quad$ No studies have been found.

In Midwest USA, 118 agricultural workers were interviewed. MSD was detected in the lumbar area (33.2\%), neck-shoulder (30.8\%) and upper extremities (21.6\%) [101].

In South Korea, 16,000 agricultural workers were interviewed, and MSD was detected in the neck or upper extremities (5.89\%), lower extremities (19.62\%) and back (26.9\%) [95]. According to the 2008 National Health Interview Survey, US agricultural workers have prevalence rates at 3 months of lower-back pain (24.3\%) and neck pain (10.5\%). The monthly prevalence was $17.0 \%$ for hips-knees, $9.8 \%$ for shoulders, $9.5 \%$ for wrists-hands,

Developed countries ${ }^{2}$ $5.4 \%$ for elbows and $4.7 \%$ for ankles-toes. Agricultural workers had a significantly higher prevalence of shoulder pain than all other industrial sector workers [200].

In the European statistics on occupational diseases (2005), MSDs were in first position on the mandatory list of occupational diseases. These disorders occur most frequently in agriculture, hunting and forestry. Travelling long distances on foot or by vehicle over rough terrain and under various weather conditions increased the risk of MSD in the lower back and knees. Finland, the Netherlands, Germany, France and Spain (datos: EU-OSHA) [282].

\footnotetext{
${ }^{1}$ Developing countries in agriculture: Iran, India, China, Malaysia, Thailand, the Solomon Islands, Borneo, Nepal, Indonesia, Morocco, Tunisia, Egypt, South Africa, Algeria, Lebanon, Colombia, El Salvador, Mexico, Brazil, Trinidad and Tobago, Panama, Guatemala and Nicaragua. ${ }^{2}$ Developed countries in agriculture: The Netherlands, Germany, Italy, Spain, Finland, France, Sweden, Serbia, Denmark, Canada, the United States, Australia, South Korea, Lithuania and New Zealand.
}

Table A17. MSD research in agriculture (1995-2020). Category: Organic agriculture.

\begin{tabular}{cl}
\hline & \multicolumn{1}{c}{ Organic Agriculture } \\
\hline Developing countries $^{1}$ & $\begin{array}{l}\text { A real and sustainable system can be created where agricultural workers } \\
\text { promote health and safety in agriculture and prevent occupational hazards. A } \\
\text { sample of 24 rice farmers (Thailand) [229]. }\end{array}$ \\
\hline Developed countries $^{2}$ & $\begin{array}{l}\text { Organic farming involves an extensive manual workload. This is challenging } \\
\text { and involves more cognitive and physical risks (USA) [230]. }\end{array}$
\end{tabular}

\footnotetext{
${ }^{1}$ Developing countries in agriculture: Iran, India, China, Malaysia, Thailand, the Solomon Islands, Borneo, Nepal, Indonesia, Morocco, Tunisia, Egypt, South Africa, Algeria, Lebanon, Colombia, El Salvador, Mexico, Brazil, Trinidad and Tobago, Panama, Guatemala and Nicaragua. ${ }^{2}$ Developed countries in agriculture: The Netherlands, Germany, Italy, Spain, Finland, France, Sweden, Serbia, Denmark, Canada, the United States, Australia, South Korea, Lithuania and New Zealand.
} 
Table A18. MSD research in agriculture (1995-2020). Category: Tools and mechanization.

\section{Tools and Mechanization}

The use of tools and mechanization in Indian agriculture is recommended [210].

In Colombia, tools were adapted for flower cultivation, thus improving the working conditions. A sample of 120 workers [211].

Developing countries ${ }^{1} \quad$ Physical burden and pain severity were reduced by adopting new technologies in the agricultural sector. A sample of 1800 workers and a subsample of 60 women (India) [212]. The use of tools and mechanization in rice cultivation increases productivity and work-time efficiency as well as reduces costs. The risks of injuries to the trunk, waist and shoulders are reduced (Malaysia). Use of REBA [213].

The use of exoskeletons (Muscle Suite-portable robot) substantially improves load handling [214].

In New Zealand, the use of quads is associated with a high prevalence of lower-back pain, followed by the neck and upper back [28].

It is necessary to apply occupational safety knowledge to farms in New Zealand where quads are used through training and by reducing exposure [215].

The age of the agricultural worker, the estimated hours of quad driving on the test day and the type of rear suspension on the quad influenced the risks of MSDs [216].

Canadian agricultural workers are frequently exposed to vibrations while operating machinery. Physical and mental loads are related to the risk of MSDs [217].

Developed countries $^{2}$ In Lithuania, the level of exposure to vibrations in small and medium-sized farms generally exceeds the exposure limit. Occupational diseases due to vibrations amount to $66 \%$ (MSD) of the total [218].

In the study on vibrations, 87 cases were analysed. MSD was associated with using agricultural machinery. There is also a greater risk of lumbar MSDs when operating such machinery (Canada) [117].

Using platforms for apple harvesting involves greater risk exposure to the upper extremities due to more repetitive movements; however, repetitions are avoided when moving up and down ladders (USA) [219].

Ergonomics tends to dampen vibrations and improve operator comfort. It is necessary to work on more ergonomic technologies and to increase worker awareness [220].

\footnotetext{
${ }^{1}$ Developing countries in agriculture: Iran, India, China, Malaysia, Thailand, the Solomon Islands, Borneo, Nepal, Indonesia, Morocco, Tunisia, Egypt, South Africa, Algeria, Lebanon, Colombia, El Salvador, Mexico, Brazil, Trinidad and Tobago, Panama, Guatemala and Nicaragua. ${ }^{2}$ Developed countries in agriculture: The Netherlands, Germany, Italy, Spain, Finland, France, Sweden, Serbia, Denmark, Canada, the United States, Australia, South Korea, Lithuania and New Zealand.
}

Table A19. MSD research in agriculture (1995-2020). Category: Automation, sensors and artificial intelligence.

\section{Automation, Sensors and Artificial Intelligence}

Developing countries ${ }^{1}$

Developed countries ${ }^{2}$
The automation of feeding in poultry farms (the Philippines) significantly reduces the workers' risk of MSD and optimizes all tasks [221].

The use of additional automated machinery (mechanized arms) in milking parlours decreased the muscular load on the workers, although the effect on the wrist positions and movements was small (Sweden) [222].

Automatic milking systems in Finland help to prevent risks and improve the productivity and sustainability of dairy production, making it more attractive to young farmers [223].

The use of artificial intelligence in agriculture to assess the safety level of workers (with sensors) when handling loads managed to predict MSD with high precision. A sample of 30 workers (Italy) [224].

The physical demands of agricultural tasks have been assessed using remote sensing. A sample of 55 workers (USA) [225].

\footnotetext{
${ }^{1}$ Developing countries in agriculture: Iran, India, China, Malaysia, Thailand, the Solomon Islands, Borneo, Nepal, Indonesia, Morocco, Tunisia, Egypt, South Africa, Algeria, Lebanon, Colombia, El Salvador, Mexico, Brazil, Trinidad and Tobago, Panama, Guatemala and Nicaragua. ${ }^{2}$ Developed countries in agriculture: The Netherlands, Germany, Italy, Spain, Finland, France, Sweden, Serbia, Denmark, Canada, the United States, Australia, South Korea, Lithuania and New Zealand.
} 


\section{References}

1. European Agency for Safety and Health at Work (EU-OSHA). National Economics and Occupational Safety and Health. Factsheet 76. Available online: https:/ / osha.europa.eu/en/publications/factsheet-76-national-economics-and-occupational-safety-andhealth/view (accessed on 4 April 2021).

2. International Labour Office (ILO). Introducción a la Seguridad y Salud Laborales. La Salud y Seguridad en el Trabajo: Colección de Módulos. (In Spanish). Available online: https:/ /www.ilo.org/global/topics/safety-and-health-at-work/resources-library / training/WCMS_115844/lang--es/index.htm (accessed on 17 June 2021).

3. International Ergonomics Association (IEA). What is Ergonomics? Available online: https://iea.cc/what-is-ergonomics/ (accessed on 1 May 2021).

4. Laurig, W.; Vedder, J.; Ergonomía. Herramientas y Enfoques. In Enciclopedia de Seguridad y Salud en el Trabajo. (In Spanish). Available online: https:/ / www.insst.es/documents/94886/161958/Capítulo+29.+Ergonomía (accessed on 1 March 2021).

5. Meyer, F.; Eweje, G.; Tappin, D. Ergonomics as a tool to improve the sustainability of the workforce. Work 2017, 57, 339-350. [CrossRef]

6. Zink, K.J. Designing sustainable work systems: The need for a system approach. Appl. Ergon. 2014, 45, 126-132. [CrossRef]

7. Martin, K.; Legg, S.; Brown, C. Designing for sustainability: Ergonomics-carpe diem. Ergonomics 2013, 56, 365-388. [CrossRef]

8. Nadadur, G.; Parkinson, M.B. The role of anthropometry in designing for sustainability. Ergonomics 2013, 56, 422-439. [CrossRef]

9. General Assembly of United Nations (UN). Transforming Our World: The 2030 Agenda for Sustainable Development; Distr. General. A/RES/70/1 Seventieth Session; United Nations: New York, NY, USA, 2015.

10. United Nations (UN). Decent Work and Economic Growth: Why It Matters. Available online: https://www.un.org/ sustainabledevelopment/wp-content/uploads/2016/08/8_Why-It-Matters-2020.pdf (accessed on 9 August 2021).

11. General Assembly of United Nations (UN). Development and International Cooperation: Environment. In Report of the World Commission on Environment and Development: Our Common Future; Distr. General. Annex to Document A/42/427; Oxford University Press: New York, NY, USA, 1987.

12. Gómez-Galán, M.; Callejón-Ferre, A.J.; Pérez-Alonso, J.; Díaz-Pérez, M.; Carrillo-Castrillo, J.A. Musculoskeletal risks: RULA bibliometric review. Int. J. Environ. Res. Public Health 2020, 17, 4354. [CrossRef] [PubMed]

13. Caffaro, F.; Roccato, M.; Micheletti-Cremasco, M.; Cavallo, E. An ergonomic approach to sustainable development: The role of information environment and social-psychological variables in the adoption of agri-environmental innovations. Sustain. Dev. 2019, 27, 1049-1062. [CrossRef]

14. López-Aragón, L.; López-Liria, R.; Callejón-Ferre, A.J.; Gómez-Galán, M. Applications of the Standardized Nordic Questionnaire: A review. Sustainability 2017, 9, 1514. [CrossRef]

15. Shuler, K.A.; Zeng, P.; Danforth, M.E. Upper limb entheseal change with the transition to agriculture in the southeastern United States: A view from Moundville and the central Tombigbee River valley. Homo 2012, 63, 413-434. [CrossRef]

16. Eshed, V.; Gopher, A.; Galili, E.; Hershkovitz, I. Musculoskeletal stress markers in Natufian hunter-gatherers and Neolithic farmers in the levant: The upper limb. Am. J. Phys. Anthr. 2004, 123, 303-315. [CrossRef] [PubMed]

17. Peterson, J. Domesticating gender: Neolithic patterns from the southern Levant. J. Anthr. Archaeol. 2010, 29, 249-264. [CrossRef]

18. Henderson, C. Subsistence strategy changes: The evidence of entheseal changes. Homo 2013, 64, 491-508. [CrossRef] [PubMed]

19. Larsen, C.S. Biological changes in human-populations with agriculture. Annu Rev. Anthr. 1995, 24, 185-213. [CrossRef]

20. Papathanasiou, A. Health status of the Neolithic population of Alepotrypa Cave, Greece. Am. J. Phys. Anthr. 2005, 126, 377-390. [CrossRef]

21. Gnes, M.; Baldoni, M.; Marchetti, L.; Basoli, F.; Leonardi, D.; Canini, A.; Licocciae, S.; Eneif, F.; Rickardsg, O.; Martínez-Labargaa, C. Bioarchaeological approach to the study of the medieval population of Santa Severa (Rome, 7th-15th centuries). J. Archaeol. Sci Rep. 2018, 18, 11-25. [CrossRef]

22. Garry, V.F.; Schreinemachers, D.; Harkins, M.E.; Griffith, J. Pesticide appliers, biocides, and birth defects in rural Minnesota. Environ. Health Perspect. 1996, 104, 394-399. [CrossRef]

23. Das, B. Gender differences in prevalence of musculoskeletal disorders among the rice farmers of West Bengal, India. Work 2015, 50, 229-240. [CrossRef] [PubMed]

24. Dianat, I.; Afshari, D.; Sarmasti, N.; Sangdeh, M.S.; Azaddel, R. Work posture, working conditions and musculoskeletal outcomes in agricultural workers. Int. J. Ind. Ergon. 2020, 77, 102941. [CrossRef]

25. Juntaracena, K.; Neubert, M.S.; Puntumetakul, R. Effects of muddy terrain on lower extremity muscle activity and discomfort during the rice planting process. Int. J. Ind. Ergon. 2018, 66, 187-193. [CrossRef]

26. Neubert, M.S.; Karukunchit, U.; Puntumetakul, R. Identification of influential demographic and work-related risk factors associated to lower extremity pain perception among rice farmers. Work 2017, 58, 489-498. [CrossRef]

27. Sang, A.J.; Tay, K.M.; Lim, C.P.; Nahavandi, S. Application of a Genetic-Fuzzy FMEA to Rainfed Lowland Rice Production in Sarawak: Environmental, Health, and Safety Perspectives. IEEE Access 2018, 6, 74628-74647. [CrossRef]

28. Milosavljevic, S.; Bergman, F.; Rehn, B.; Carman, A.B. All-terrain vehicle use in agriculture: Exposure to whole body vibration and mechanical shock. Appl. Ergon. 2010, 41, 530-535. [CrossRef] [PubMed]

29. Fels, D.I.; Blackler, A.; Cook, D.; Foth, M. Ergonomics in apiculture: A case study based on inspecting movable frame hives for healthy bee activities. Heliyon 2019, 5, e01973. [CrossRef] [PubMed] 
30. Chattha, H.S.; Corscadden, K.W.; Zaman, Q.U. Hazard Identification and Risk Assessment for Improving Farm Safety on Canadian Farms. J. Agric. Saf. Health 2017, 23, 155-174. [CrossRef]

31. Carrington, J.M.; Poole, J.A. The Effect of Inhalant Organic Dust on Bone Health. Curr. Allergy Asthm. R 2018, 18, 16. [CrossRef] [PubMed]

32. Staab, E.; Thiele, G.M.; Clarey, D.; Wyatt, T.A.; Romberger, D.J.; Wells, A.D.; Wang, D.; Klassen, L.W.; Mikuls, T.R.; Duryee, M.J.; et al. Toll-Like Receptor 4 Signaling Pathway Mediates Inhalant Organic Dust-Induced Bone Loss. PLoS ONE 2016, 11, e0158735. [CrossRef]

33. Malanski, P.D.; Schiavi, S.; Dedieu, B. Characteristics of "work in agriculture" scientific communities. A bibliometric review. Agron. Sustain. Dev. 2019, 39, 36. [CrossRef]

34. European Agency for Safety and Health at Work (EU-OSHA). Risk Assessment of Upper Limb Musculoskeletal Disorders in Agriculture: Compared Experiences. Available online: https:/ / osha.europa.eu/en/publications/risk-assessment-upper-limbmusculoskeletal-disorders-agriculture-compared-experiences/view (accessed on 8 September 2021).

35. European Agency for Safety and Health at Work (EU-OSHA). Staying Safe Down on the Farm: Reducing the Risk of Musculoskeletal Disorders among Agricultural Workers. Available online: https:/ / osha.europa.eu/en/highlights/staying-safe-downfarm-reducing-risk-musculoskeletal-disorders-among-agricultural-workers (accessed on 8 September 2021).

36. Jain, R.; Meena, M.L.; Dangayach, G.S.; Bhardwaj, A.K. Association of risk factors with musculoskeletal disorders in manualworking farmers. Arch. Environ. Occup. Health 2018, 73, 19-28. [CrossRef]

37. European Agency for Safety and Health at Work (EU-OSHA). Introduction to Work-Related Musculoskeletal Disorders. Factsheet 71. Available online: https:/ / osha.europa.eu/en/publications/factsheet-71-introduction-work-related-musculoskeletaldisorders/view (accessed on 4 April 2021).

38. Gómez-Galán, M.; Pérez-Alonso, J.; Callejón-Ferre, A.J.; López-Martínez, J. Musculoskeletal disorders: OWAS review. Ind. Health 2017, 55, 314-337. [CrossRef]

39. Álvarez-Zárate, J.M.; Marín-Zurdo, J.J.; Sistema HADA Move-Human Sensors. Sistema Portátil para Captura Y Análisis Tridimensional del Movimiento Humano en Puestos de Trabajo Basado en Sensores Inerciales de Movimiento Y Simulación 3D CON MODELOS BIOMECÁNICOS. (In Spanish). Available online: http:/ / www.seguridad-laboral.es/prevencion/ergonomia/ sistema-hada-move-human-sensors (accessed on 27 June 2021).

40. Dutta, T. Evaluation of the Kinect (TM) sensor for 3-D kinematic measurement in the workplace. Appl. Ergon. 2012, 43, 645-649. [CrossRef]

41. Kuorinka, L.; Jonson, B.; Kilbom, A.; Viterberg, H.; BierNing-Sorensen, F.; Andersson, G.; Jorgensen, K. Standardized Nordic questionnaires for the analysis of musculoskeletal symptoms. Appl. Ergon. 1987, 18, 233-237. [CrossRef]

42. Lifshitz, Y.; Armstrong, T. A design checklist for control and prediction of cumulative trauma disorders in hand intensive manual jobs. In Proceedings of the 30th Annual Meeting of Human Factors Society, Michigan, MI, USA, 29 September-3 October 1986; pp. 837-841.

43. David, G.; Woods, V.; Li, G.; Buckle, P. The development of the Quick Exposure Check for assessing exposure to risk factors for work-related musculoskeletal disorders. Appl. Ergon. 2008, 39, 57-69. [CrossRef] [PubMed]

44. Keyserling, W.M.; Stetson, D.S.; Silverstein, B.A.; Brouwer, M.L. A checklist for evaluating ergonomic risk factors associated with upper extremity cumulative trauma disorders. Ergonomics 1993, 36, 807-831. [CrossRef]

45. Jürgens, W.W.; Mohr, D.; Pangert, R.; Pernack, E.; Schultz, K.; Steinberg, U. Handlungsanleitung zur Beurteilung der Arbeitsbedingungen beim Heben und Tragen von Lasten; LASI Veröffentlichung: Wiesbaden, Germany, 2001.

46. Instituto Nacional de Seguridad y Salud en el Trabajo (INSST). Guía Técnica Para la Evaluación y Prevención de los Riesgos Relativos a la Manipulación Manual de Cargas; Guías Técnicas: Madrid, Spain, 1998. (In Spanish)

47. Monnington, S.C.; Quarrie, C.J.; Pinder, A.D.J.; Morris, L.A. Development of manual handling assessment charts (MAC) for health and safety inspectors. In Contemporary Ergonomics; Taylor \& Francis: London, UK, 2003.

48. Liberty-Mutual. Manual Materials Handling Tables. Available online: https://libertymmhtables.libertymutual.com/CM_ LMTablesWeb/taskSelection.do?action=initTaskSelection (accessed on 2 May 2021).

49. National Institute for Occupational Safety and Health (NIOSH). Work Practices Guide for Manual Lifting; NIOSH Technical Report; NIOSH: Cincinnaty, OH, USA, 1981; pp. 81-122.

50. Snook, S.H.; Ciriello, V.M. The design of manual handling tasks: Revised tables of maximum acceptable weights and forces. Ergonomics 1991, 34, 1197-1213. [CrossRef]

51. McAtamney, L.; Corlett, E.N. RULA-A survey method for the investigation of work-related upper limb disorders. Appl. Ergon. 1993, 24, 91-99. [CrossRef]

52. Colombini, D. An observational method for classifying exposure to repetitive movements of the upper limbs. Ergonomics 1998, 41, 1261-1289. [CrossRef] [PubMed]

53. Kemmlert, K. A method assigned for the identification of ergonomic hazards-PLIBEL. Appl. Ergon. 1995, 26, 199-211. [CrossRef]

54. Moore, J.S.; Garg, A. The Strain Index: A proposed method to analyze jobs for risk of distal upper extremity disorders. Am. Ind. Hyg. Assoc. J. 1995, 56, 443-458. [CrossRef]

55. García, C.; Chirivela, C.; Page del Pozo, A.; Moraga, R.; Jorquera, J. Método Ergo IBV. Evaluación de Riesgos Laborales Asociados a la Carga Física; Instituto de Biomecánica de Valencia (IBV): Valencia, Spain, 1997. 
56. James, C.P.A.; Harburn, K.L.; Kramer, J.F. Cumulative trauma disorders in the upper extremities: Reliability of the Postural and Repetitive Risk-Factors Index. Arch. Phys. Med. Rehabil. 1997, 78, 860-866. [CrossRef]

57. Hignett, S.; McAtamney, L. Rapid Entire Body Assessment (REBA). Appl. Ergon. 2000, 31, 201-205. [CrossRef]

58. Buchholz, B.; Paquet, V.; Punnett, L.; Lee, D.; Moir, S. PATH: A work sampling-based approach to ergonomic job analysis for construction and other non-repetitive work. Appl. Ergon. 1996, 27, 177-187. [CrossRef]

59. Karhu, O.; Kansi, P.; Kuorinka, I. Correcting working postures in industry: A practical method for analysis. Appl. Ergon. 1977, 8 , 199-201. [CrossRef]

60. Kilbom, A.; Persson, J.; Jonsson, B. Risk factors for work-related disorders of the neck and shoulder-With special emphasis on working postures and movements. In The Ergonomics of Working Postures; Corlett, E.N., Wilson, J., Manenica, I., Eds.; Taylor \& Francis: London, UK, 1986; pp. 44-53.

61. Corlett, E.; Madeley, S.; Manenica, I. Posture targeting: A technique for recording working postures. Ergonomics 1979, 22, 357-633. [CrossRef]

62. Hita-Gutierrez, M.; Gomez-Galan, M.; Diaz-Perez, M.; Callejon-Ferre, A.J. An overview of REBA method applications in the world. Int. J. Environ. Res. Public Health 2020, 17, 2635. [CrossRef]

63. Deeney, C.; O'Sullivan, L. Work related psychosocial risks and musculoskeletal disorders: Potential risk factors, causation and evaluation methods. Work 2009, 34, 239-248. [CrossRef]

64. European Agency for Safety and Health at Work (EU-OSHA). Work-Related Musculoskeletal Disorders: Back to Work. Factsheet 75. Available online: https://osha.europa.eu/en/publications/factsheet-75-work-related-musculoskeletal-disorders-backwork/view (accessed on 1 March 2021).

65. European Agency for Safety and Health at Work (EU-OSHA). Work-Related Musculoskeletal Disorders: Prevention REPORT. A Summary. Factsheet 78. Available online: https://osha.europa.eu/en/publications/factsheet-78-work-related-musculoskeletaldisorders-prevention-report-summary/view (accessed on 1 March 2021).

66. International Labour Organization (ILO). Musculoskeletal Disorders. Available online: http://www.ilo.org/wcmsp5/groups / public/---ed_protect/---protrav/---safework/documents/presentation/wcms_232617.pdf (accessed on 10 May 2021).

67. Llaneza-Álvarez, F.J. Ergonomía y Psicosociología Aplicada. Manual Para la Formación del Especialista, 10th ed.; Lex Nova: Madrid, Spain, 2008; p. 295. (In Spanish)

68. Lee, H.; Wilbur, J.; Kim, M.J.; Miller, A.M. Pshychosocial risk factors for work-related musculoskeletal disorders of the lower-back among long-haul international female flight attendants. J. Adv. Nurs. 2008, 61, 492-502. [CrossRef] [PubMed]

69. Zakerian, S.A.; Subramaniam, I.D. The relationship between psychosocial work factors, work stress and computer-related musculoskeletal discomforts among computer users in Malaysia. Int. J. Occup. Saf. Ergon. 2009, 15, 425-434. [CrossRef]

70. Haukka, E.; Leino-Arjas, P.; Ojajarvi, A.; Takala, E.P.; Viikari-Juntura, E.; Riihimaki, H. Mental stress and psychosocial factors at work in relation to multiple-site musculoskeletal pain: A longitudinal study of kitchen workers. Eur. J. Pain 2011, 15, $432-438$. [CrossRef]

71. Mehrdad, R.; Dennerlein, J.T.; Haghighat, M.; Aminian, O. Association between psychosocial factors and musculoskeletal symptoms among Iranian nurses. Am. J. Ind. Med. 2010, 53, 1032-1039. [CrossRef]

72. Sembajwe, G.; Tveito, T.H.; Hopcia, K.; Kenwood, C.; O’Day, E.T.; Stoddard, A.M.; Dennerlein, J.T.; Hashimoto, D.; Sorensen, G. Psychosocial stress and multi-site musculoskeletal pain a cross-sectional survey of patient care workers. Workplace Health Saf. 2013, 61, 117-125. [CrossRef]

73. Rohles, F.H. Environmental ergonomics in agricultural systems. Appl. Ergon. 1985, 16, 163-166. [CrossRef]

74. Marras, W.S.; Hancock, P.A. Putting mind and body back together: A human-systems approach to the integration of the physical and cognitive dimensions of task design and operations. Appl. Ergon. 2014, 45, 55-60. [PubMed]

75. Das, B.; Ghosh, T.; Gangopadhyay, S. Child Work in Agriculture in West Bengal, India: Assessment of Musculoskeletal Disorders and Occupational Health Problems. J. Occup. Health 2013, 55, 244-258. [CrossRef] [PubMed]

76. LeBrun, D.G.; Talwar, D.; Pham, T.A.; Banskota, B.; Spiegel, D.A. Predictors of healthcare seeking delays among children with chronic musculoskeletal disorders in Nepal. J. Epidemiol. Glob. Health 2017, 7, 299-304. [CrossRef] [PubMed]

77. Perkio-Makela, M.M. Finnish farmers' self-reported morbidity, work ability, and functional capacity. Ann. Agric. Environ. Med. 2000, 7, 11-16.

78. Perry, M.J. Children's agricultural health: Traumatic injuries and hazardous inorganic exposures. J. Rural Health 2003, 19, 269-278.

79. Chapman, L.J.; Taveira, A.D.; Karsh, B.T.; Josefsson, K.G.; Newenhouse, A.C.; Meyer, R.H. Work Exposures, Injuries, and Musculoskeletal Discomfort Among Children and Adolescents in Dairy Farming. J. Agromed. 2009, 14, 9-21.

80. Kallioniemi, M.K.; Kymalainen, H.R. Women on Finnish dairy farms: Hard work in the midst of traditions and changes. Rural Soc. 2012, 22, 78-89. [CrossRef]

81. Arcury, T.A.; Rodriguez, G.; Kearney, G.D.; Arcury, J.T.; Quandt, S.A. Safety and Injury Characteristics of Youth Farmworkers in North Carolina: A Pilot Study. J. Agromed. 2014, 19, 354-363. [CrossRef]

82. Rappazzo, K.M.; Warren, J.L.; Meyer, R.E.; Herring, A.H.; Sanders, A.P.; Brownstein, N.C.; Luben, T.J. Maternal residential exposure to agricultural pesticides and birth defects in a 2003 to 2005 North Carolina birth cohort. Birth Defects Res. A 2016, 106, 240-249. [CrossRef]

83. Pinzke, S. Comparison of Working Conditions and Prevalence of Musculoskeletal Symptoms among Dairy Farmers in Southern Sweden over a 25-Year Period. Front. Public Health 2016, 4, 98. 
84. Swangnetr, M.; Kaber, D.B.; Puntumetakul, R.; Gross, M.T. Ergonomics-related risk identification and pain analysis for farmers involved in rice field preparation. Work 2014, 49, 63-71. [CrossRef]

85. Hoy, D.G.; Raikoti, T.; Smith, E.; Tuzakana, A.; Gill, T.; Matikarai, K.; Tako, J.; Jorari, A.; Blyth, F.; Pitaboe, A.; et al. Use of The Global Alliance for Musculoskeletal Health survey module for estimating the population prevalence of musculoskeletal pain: Findings from the Solomon Islands. BMC Musculoskelet. Dis. 2018, 19, 292. [CrossRef] [PubMed]

86. Cecchini, M.; Bedini, R.; Mosetti, D.; Marino, S.; Stasi, S. Safety Knowledge and Changing Behavior in Agricultural Workers: An Assessment Model Applied in Central Italy. Saf. Health Work 2018, 9, 164-171. [CrossRef] [PubMed]

87. Arcury, T.A.; Arnold, T.J.; Quandt, S.A.; Chen, H.Y.; Kearney, G.D.; Sandberg, J.C.; Talton, J.W.; Wiggins, M.F.; Daniel, S.S. Health and Occupational Injury Experienced by Latinx Child Farmworkers in North Carolina, USA. Int. J. Environ. Res. Public Health 2020, 17, 248. [CrossRef] [PubMed]

88. Kaewdok, T.; Sirisawasd, S.; Taptagaporn, S. Agricultural risk factors related musculoskeletal disorders among older farmers in Pathum Thani province, Thailand. J. Agromed. 2020, 26, 185-192. [CrossRef] [PubMed]

89. Baksh, K.S.; Ganpat, W.; Narine, L.K. Occupational Health and Safety Issues among Vegetable Farmers in Trinidad and the Implications for Extension. J. Agric. Saf. Health 2015, 21, 159-171.

90. Jain, R.; Meena, M.L.; Dangayach, G.S.; Bhardwaj, A.K. Risk factors for musculoskeletal disorders in manual harvesting farmers of Rajasthan. Ind. Health 2018, 56, 241-248. [CrossRef]

91. Lee, K.; Lim, H.S. Work-related injuries and diseases of farmers in Korea. Ind. Health 2008, 46, 424-434. [CrossRef]

92. Lee, C.G. Work-related musculoskeletal disorders in Korean farmers. J. Korean Med. Assoc. 2012, 55, 1054-1062. [CrossRef]

93. Peres, K.; Matharan, F.; Allard, M.; Amieva, H.; Baldi, I.; Barberger-Gateau, P.; Bergua, V.; Bourdel-Marchasson, I.; Delcourt, C.; Foubert-Samier, A.; et al. Health and aging in elderly farmers: The AMI cohort. BMC Public Health 2012, 12, 558. [CrossRef]

94. Trask, C.; Bath, B.; McCrosky, J.; Lawson, J. A Profile of Farmers and Other Employed Canadians with Chronic Back Pain: A Population-Based Analysis of the 2009-2010 Canadian Community Health Surveys. J. Rural Health 2014, 30, 300-310. [CrossRef]

95. Kang, M.Y.; Lee, M.J.; Chung, H.; Shin, D.H.; Youn, K.W.; Im, S.H.; Chae, H.S.; Lee, K.S. Musculoskeletal Disorders and Agricultural Risk Factors Among Korean Farmers. J. Agromed. 2016, 21, 353-363. [CrossRef]

96. Perkio-Makela, M.; Hirvonen, M. How to Improve Farmers' Work Ability. In Proceedings of the 20th Congress of The International Ergonomics Association (iea 2018), vol 8: Ergonomics and human factors in manufacturing, agriculture, building and construction, sustainable development and mining. Book Ser. Adv. Intell Syst Comput. 2019, 825, 367-374. [CrossRef]

97. Henry, L.J.; Esfehani, A.J.; Ramli, A.; Ishak, I.; Justine, M.; Mohan, V. Patterns of Work-Related Musculoskeletal Disorders Among Workers in Palm Plantation Occupation. Asia Pac. J. Public Health 2015, 7, NP1785-NP1792. [CrossRef] [PubMed]

98. Ng, Y.G.; Tamrin, S.B.M.; Yusoff, I.S.M.; Hashim, Z.; Deros, B.M.D.; Bakar, S.A.; How, V. Risk factors of musculoskeletal disorders among oil palm fruit harvesters during early harvesting stage. Ann. Agric. Environ. Med. 2015, 22, 286-292. [CrossRef] [PubMed]

99. Thetkathuek, A.; Meepradit, P.; Sa-ngiamsak, T. A Cross-sectional Study of Musculoskeletal Symptoms and Risk Factors in Cambodian Fruit Farm Workers in Eastern Region, Thailand. Saf. Health Work 2018, 9, 192-202. [CrossRef] [PubMed]

100. Douphrate, D.I.; Gimeno, D.; Nonnenmann, M.W.; Hagevoort, R.; Rosas-Goulart, C.; Rosecrance, J.C. Prevalence of Work-Related Musculoskeletal Symptoms Among US Large-Herd Dairy Parlor Workers. Am. J. Ind. Med. 2014, 57, 370-379. [CrossRef]

101. Fethke, N.B.; Merlino, L.A.; Gerr, F.; Schall, M.C.; Mark, C.; Branch, C.A. Musculoskeletal Pain Among Midwest Farmers and Associations with Agricultural Activities. Am. J. Ind. Med. 2015, 58, 319-330. [CrossRef]

102. Kociolek, A.M.; Lang, A.E.; Trask, C.M.; Vasiljev, R.M.; Milosavljevic, S. Exploring head and neck vibration exposure from quad bike use in agriculture. Int. J. Ind. Ergon. 2018, 66, 63-69. [CrossRef]

103. Barrero, L.H.; Hsu, Y.H.; Terwedow, H.; Perry, M.J.; Dennerlein, J.T.; Brain, J.D.; Xu, X. Prevalence and physical determinants of low back pain in a rural Chinese population. Spine 2006, 31, 2728-2734. [CrossRef]

104. Meucci, R.D.; Fassa, A.G.; Faria, N.M.X.; Fiori, N.S. Chronic low back pain among tobacco farmers in southern Brazil. Int. J. Occup. Environ. Heath. 2015, 21, 66-73. [CrossRef] [PubMed]

105. Ganesh, S.; Chhabra, D.; Kumari, N. The effectiveness of rehabilitation on pain-free farming in agriculture workers with low back pain in India. Work 2016, 55, 399-411. [CrossRef]

106. Kumaraveloo, K.S.; Kolstrup, C.L. Agriculture and musculoskeletal disorders in low- and middle-income countries. J. Agromed. 2018, 23, 227-248. [CrossRef] [PubMed]

107. Momeni, Z.; Choobineh, A.; Razeghi, M.; Ghaem, H.; Azadian, F.; Daneshmandi, H. Work-related Musculoskeletal Symptoms among Agricultural Workers: A Cross-sectional Study in Iran. J. Agromed. 2020, 25, 339-348. [CrossRef]

108. Nevala Puranen, N. Reduction of farmers' postural load during occupationally oriented medical rehabilitation. Appl. Ergon. 1995, 26, 411-415. [CrossRef]

109. Rosecrance, J.; Rodgers, G.; Merlino, L. Low back pain and musculoskeletal symptoms among Kansas farmers. Am. J. Ind. Med. 2006, 49, 547-556. [CrossRef]

110. Fathallah, F.A.; Miller, B.J.; Miles, J.A. Low Back Disorders in Agriculture and the Role of Stooped Work: Scope, Potential Interventions, and Research Needs. J. Agric. Saf. Health 2008, 14, 221-245. [CrossRef]

111. Earle-Richardson, G.; Jenkins, P.L.; Strogatz, D.; Bell, E.M.; Freivalds, A.; Sorensen, J.A. Electromyographic assessment of apple bucket intervention designed to reduce back strain. Ergonomics 2008, 51, 902-919. [CrossRef] [PubMed]

112. Mayton, A.G.; Kittusamy, N.K.; Ambrose, D.H.; Jobes, C.C.; Legault, M.L. Jarring/jolting exposure and musculoskeletal symptoms among farm equipment operators. Int. J. Ind. Ergon. 2008, 38, 758-766. [CrossRef] 
113. Brumitt, J.; Reisch, R.; Krasnoselsky, K.; Welch, A.; Rutt, R.; Garside, L.I. Self-Reported Musculoskeletal Pain in Latino Vineyard Workers. J. Agromed. 2011, 16, 72-80. [CrossRef]

114. Roh, S. Work-related diseases of agricultural workers in South Korea. J. Korean Med. Assoc. 2012, 55, 1063-1069. [CrossRef]

115. Ulrey, B.L.; Fathallah, F.A. Effect of a personal weight transfer device on muscle activities and joint flexions in the stooped posture. J. Electromyogr. Kines. 2013, 23, 195-205. [CrossRef]

116. Xiao, H.; McCurdy, S.A.; Stoecklin-Marois, M.T.; Li, C.S.; Schenker, M.B. Agricultural work and chronic musculoskeletal pain among latino farm workers: The MICASA study. Am. J. Ind. Med. 2013, 56, 216-225. [CrossRef]

117. Zeng, X.K.; Kociolek, A.M.; Khan, M.I.; Milosavljevic, S.; Bath, B.; Trask, C. Whole body vibration exposure patterns in Canadian prairie farmers. Ergonomics 2017, 60, 1064-1073. [CrossRef]

118. Balaguier, R.; Madeleine, P.; Rose-Dulcina, K.; Vuillerme, N. Effects of a Worksite Supervised Adapted Physical Activity Program on Trunk Muscle Endurance, Flexibility, and Pain Sensitivity Among Vineyard Workers. J. Agromed. 2017, 22, 200-214. [CrossRef] [PubMed]

119. Jo, H.; Park, H.W.; Baek, S.; Kang, E.K. Low back pain in farmers: The association with agricultural work management, disability, and quality of life in Korean farmers. Hum. Factor Ergon. Man. 2017, 27, 156-165. [CrossRef]

120. Kong, E.K.; Park, H.W.; Kim, S.H.; Baek, S. Clinical Usefulness of X-Ray Findings for Non-specific Low Back Pain in Korean Farmers: FARM Study. Ann. Rehabil. Med. 2017, 41, 808-815. [CrossRef]

121. Godilano, E.C.; Casas, K.V.; Vargas, A.J. Design of an Ergonomic Wheelbarrow to Reduce Physiological Demands of General Users In Proceedings of the 5th International Conference on Industrial Engineering and Applications (ICIEA), National University Singapore, Shaw Fdn Alumni House, Singapore, 26-28 April 2018.

122. Essien, S.K.; Trask, C.; Khan, M.; Boden, C.; Bath, B. Association Between Whole-Body Vibration and Low-Back Disorders in Farmers: A Scoping Review. J. Agromed. 2018, 23, 105-120. [CrossRef] [PubMed]

123. Khan, M.I.; Bath, B.; Kociolek, A.; Zeng, X.K.; Koehncke, N.; Trask, C. Trunk Posture Exposure Patterns among Prairie Ranch and Grain Farmers. J. Agromed. 2020, 5, 210-220. [CrossRef] [PubMed]

124. Benos, L.; Tsaopoulos, D.; Bochtis, D. A Review on Ergonomics in Agriculture. Part I: Manual Operations. Appl. Sci. 2020, 10, 1905. [CrossRef]

125. Swangnetr, M.; Kaber, D.; Phimphasak, C.; Namkorn, P.; Saenlee, K.; Zhu, B.; Puntumetakul, R. The influence of rice plow handle design and whole-body posture on grip force and upper-extremity muscle activation. Ergonomics 2014, 57, 1526-1535. [CrossRef]

126. Barrero, L.H.; Pulido, J.A.; Berrio, S.; Monroy, M.; Quintana, L.A.; Ceballos, C. Physical workloads of the upper-extremity among workers of the Colombian flower industry. Am. J. Ind. Med. 2012, 55, 926-939. [CrossRef]

127. Berrio, S.; Barrero, L.H. Effect of Time Elapsed since Last Pruner Maintenance on Upper-Extremity Biomechanics during Manual Flower Cutting. J. Agromed. 2018, 23, 166-175. [CrossRef]

128. NevalaPuranen, N.; Kallionpaa, M.; Ojanen, K. Physical load and strain in parlor milking. Int. J. Ind. Ergon. 1996, 18, 277-282. [CrossRef]

129. Palmer, K.T. Musculoskeletal problems in the tomato growing industry: 'Tomato trainer's shoulder'? Occup. Med. Oxf. 1996, 46, 428-431. [CrossRef] [PubMed]

130. Dillon, C.; Petersen, M.; Tanaka, S. Self-reported hand and wrist arthritis and occupation: Data from the US National Health Interview Survey-Occupational Health Supplement. Am. J. Ind. Med. 2002, 42, 318-327. [CrossRef] [PubMed]

131. Shah, D.J.; Shipp, E.M.; Cooper, S.P.; Huber, J.C.; del Junco, D.J.; Rene, A.A. Hand Problems in Migrant Farmworkers. J. Agric. Saf. Health 2009, 15, 157-169. [CrossRef] [PubMed]

132. Douphrate, D.I.; Fethke, N.B.; Nonnenmann, M.W.; Rosecrance, J.C.; Reynolds, S.J. Full shift arm inclinometry among dairy parlor workers: A feasibility study in a challenging work environment. Appl. Ergon. 2012, 43, 604-613. [CrossRef]

133. Kolstrup, C.L. Work-related musculoskeletal discomfort of dairy farmers and employed workers. J. Occup. Med. Toxicol. 2012, 7, 23. [CrossRef]

134. Calvo, A.; Deboli, R.; Preti, C.; De Maria, A. Daily exposure to hand arm vibration by different electric olive beaters. J. Agric. Eng. 2014, 45, 103-110. [CrossRef]

135. Kuta, L.; Brennensthul, M. The Causes of Disorder's Development Among Farmers as a Result of Mechanized Tasks. Sci. Pap. Ser. Manag. Econ. Eng. Agric. Rural Dev. 2015, 15, 177-182.

136. Gyemi, D.L.; van Wyk, P.M.; Statham, M.; Casey, J.; Andrews, D.M. 3D peak and cumulative low back and shoulder loads and postures during greenhouse pepper harvesting using a video-based approach. Work 2016, 55, 817-829. [CrossRef] [PubMed]

137. Douphrate, D.I.; Nonnenmann, M.W.; Hagevoort, R.; de Porras, D.G.R. Work-Related Musculoskeletal Symptoms and Job Factors Among Large-Herd Dairy Milkers. J. Agromed. 2016, 21, 24-233. [CrossRef]

138. Bosch, L.M.; van der Molen, H.F.; Frings-Dresen, M.H.W. Optimizing implementation of interventions in agriculture for occupational upper extremity musculoskeletal disorders: Results of an expert panel. Work 2018, 61, 413-420. [CrossRef] [PubMed]

139. Pardo-Ferreira, M.C.; Zambrana-Ruiz, A.; Carrillo-Castrillo, J.A.; Rubio-Romero, J.C. Ergonomic risk management of pruning with chainsaw in the olive sector. In Proceedings of the 6th International Symposium on Occupational Safety and Hygiene (SHO), Guimaraes, Portugal, 26-27 March 2018.

140. Kim, E.; Freivalds, A.; Takeda, F.; Li, C. Ergonomic Evaluation of Current Advancements in Blueberry Harvesting. Agronomy 2018, 8, 266. [CrossRef] 
141. Oksa, P.; Sauni, R.; Talola, N.; Virtanen, S.; Nevalainen, J.; Saalo, A. Trends in occupational diseases in Finland, 1975-2013: A register study. BMJ Open 2019, 9, e024040. [CrossRef]

142. Ya'acob, N.A.; Abidin, E.Z.; Rasdi, I.; Abd Rahman, A.; Ismail, S. Reducing work-related musculoskeletal symptoms through implementation of Kiken Yochi training intervention approach. Work 2018, 60, 143-152. [CrossRef] [PubMed]

143. Kotowski, S.E.; Davis, K.G.; Kim, H.; Lee, K.S. Identifying risk factors of musculoskeletal disorders on Korean farms. Work 2014, 49, 15-23. [CrossRef] [PubMed]

144. Nawi, N.S.M.; Deros, B.M.; Nordin, N. Assessment of Oil Palm Fresh Fruit Bunches Harvesters Working Postures Using Reba. Curr. Trends Ergon. 2013, 10, 122. [CrossRef]

145. Ng, Y.G.; Bahri, M.T.S.; Syah, M.Y.I.; Mori, I.; Hashim, Z. Ergonomics Observation: Harvesting Tasks at Oil Palm Plantation. J. Occup. Health 2013, 55, 405-414. [CrossRef]

146. Ng, Y.G.; Tamrin, S.B.M.; Yik, W.M.; Yusoff, I.S.M.; Mori, I. The Prevalence of Musculoskeletal Disorder and Association with Productivity Loss: A Preliminary Study among Labour Intensive Manual Harvesting Activities in Oil Palm Plantation. Ind. Health 2014, 52, 78-85. [CrossRef] [PubMed]

147. Rojas, M.; Gimeno, D.; Vargas-Prada, S.; Benavides, F.G. Musculoskeletal pain in Central American workers: Results of the First Survey on Working Conditions and Health in Central America. Rev. Panam. Salud. Publ. 2015, 38, 120-128.

148. Taylor-Gjevre, R.M.; Trask, C.; King, N.; Koehncke, N. Prevalence and Occupational Impact of Arthritis in Saskatchewan Farmers. J. Agromed. 2015, 20, 205-216. [CrossRef] [PubMed]

149. Proto, A.R.; Zimbalatti, G. Risk Assessment of Repetitive Movements in Olive Growing: Analysis of Annual Exposure Level Assessment Models with the OCRA Checklist. J. Agric. Saf. Health 2015, 21, 241-253. [PubMed]

150. Kouimintzis, D.; Chatzis, C.; Linos, A. Health effects of livestock farming in Europe. Z. Gesundh Wiss. 2007, 15, 245-254. [CrossRef]

151. Douphrate, D.I.; Nonnenmann, M.W.; Rosecrance, J.C. Ergonomics in Industrialized Dairy Operations. J. Agromed. 2009, 14, 406-412. [CrossRef]

152. Schall, M.C.; Fethke, N.B.; Chen, H.; Oyama, S.; Douphrate, D.I. Accuracy and repeatability of an inertial measurement unit system for field-based occupational studies. Ergonomics 2016, 59, 591-602. [CrossRef] [PubMed]

153. Kolstrup, C.L.; Jakob, M. Epidemiology of Musculoskeletal Symptoms Among Milkers and Dairy Farm Characteristics in Sweden and Germany. J. Agromed. 2016, 21, 43-55. [CrossRef]

154. Pinzke, S. Changes in working conditions and health among dairy farmers in southern Sweden. A 14-year follow-up. Ann. Agric. Environ. Med. 2003, 10, 185-195.

155. Kuta, L.; Ciez, J.; Golab, I. Assessment of Workload on Musculoskeletal System of Milkers in Mechanical Milking Through the Use of Job Strain Index Method. Sci. Pap. Ser. Manag. Econ. Eng. Agric. Rural Dev. 2015, 15, $249-254$.

156. Douphrate, D.I.; Fethke, N.B.; Nonnenmann, M.W.; Rodriguez, A.; Hagevoort, R.; de Porras, D.G.R. Full-shift and task-specific upper extremity muscle activity among US large-herd dairy parlor workers. Ergonomics 2017, 60, 1042-1054. [CrossRef]

157. Douphrate, D.I.; de Porras, D.G.R.; Nonnenmann, M.W.; Hagevoort, R.; Reynolds, S.J.; Rodriguez, A. Effects of milking unit design on upper extremity muscle activity during attachment among US large-herd parlor workers. Appl. Ergon. 2017, 58, 482-490. [CrossRef]

158. Douphrate, D.I.; Fethke, N.B.; Nonnenmann, M.W.; Rodriguez, A.; Hagevoort, G.R.; de Porras, D.G.R. Effect of a novel teat preparation system on upper extremity muscle activity among US large-herd dairy parlor workers. Int. J. Ind. Ergon. 2016, 56, 161-169. [CrossRef]

159. Douphrate, D.I.; Kolstrup, C.L.; Nonnenmann, M.W.; Jakob, M.; Pinzke, S. Ergonomics in Modern Dairy Practice: A Review of Current Issues and Research Needs. J. Agromed. 2013, 18, 198-209. [CrossRef]

160. Kuta, L.; Ciez, J.; Mlotek, M. Musculoskeletal load assessment of farmers during selected agricultural works. In Proceedings of the 6th International Conference on Applied Human Factors and Ergonomics (AHFE), Las Vegas, NV, USA, 26-30 July 2015.

161. Lofqvist, L.; Osvalder, A.L.; Bligard, L.O.; Pinzke, S. An analytical ergonomic risk evaluation of body postures during daily cleaning tasks in horse stables. Work 2015, 51, 667-682. [CrossRef] [PubMed]

162. Swanberg, J.E.; Clouser, J.M.; Westneat, S.C.; Marsh, M.W.; Reed, D.B. Occupational Injuries on Thoroughbred Horse Farms: A Description of Latino and Non-Latino Workers' Experience. Int. J. Environ. Res. Public Health 2013, 10, 6500-6516. [CrossRef]

163. Swanberg, J.E.; Clouser, J.M.; Westneat, S. Work organization and occupational health: Perspectives from Latinos employed on crop and horse breeding farms. Am. J. Ind. Med. 2012, 55, 714-728. [CrossRef] [PubMed]

164. Trask, C. Preliminary Ergonomic Evaluation of Barn Tasks in Intensive Swine Production. J. Agromed. 2013, 18, 368-378. [CrossRef] [PubMed]

165. Singh, S.; Sinwal, N.; Rathore, H. Gender involvement in manual material handling (mmh) tasks in agriculture and technology intervention to mitigate the resulting musculoskeletal disorders. Work 2012, 41, 4333-4341.

166. Belcore, E.; Pezzoli, A.; Calvo, A. Analysis of gender vulnerability to climate-related hazards in a rural area of Ethiopia. Geogr. J. 2020, 186, 156-170. [CrossRef]

167. García, A.M.; Fletcher, T.; Benavides, F.G.; Orts, E. Parental agricultural work and selected congenital malformations. Am. J. Epidemiol. 1999, 149, 64-74. [CrossRef] [PubMed]

168. Roquelaure, Y.; Gabignon, Y.; Gillant, J.C.; Delalieux, P.; Ferrari, C.; Mea, M. Transient hand paresthesias in Champagne vineyard workers. Am. J. Ind. Med. 2001, 40, 639-645. [CrossRef] [PubMed] 
169. Stal, M.; Englund, J.E. Gender Difference in Prevalence of Upper Extremity Musculoskeletal Symptoms Among Swedish Pig Farmers. J. Agric. Saf. Health 2005, 11, 7-17. [CrossRef]

170. Thinius, M.; Jakob, M. Ergonomic workplace evaluation and epidemiology of musculoskeletal discomfort on German dairy farms. Work 2014, 49, 25-32. [CrossRef]

171. Trask, C.; Khan, M.I.; Adebayo, O.; Boden, C.; Bath, B. Equity in Whom Gets Studied: A Systematic Review Examining Geographical Region, Gender, Commodity, and Employment Context in Research of Low Back Disorders in Farmers. J. Agromed. 2015, 20, 273-281. [CrossRef] [PubMed]

172. Raczkiewicz, D.; Owoc, A.; Sarecka-Hujar, B.; Bojar, I. Pain involving the motor system and serum vitamin D concentration in postmenopausal women working in agriculture. Ann. Agric. Environ. Med. 2017, 24, 151-155. [CrossRef]

173. Calvo, A.; Airoldi, G. Sizing Milking Groups in Small Cow Dairies of Mediterranean Countries. Animals 2020, 10, 795. [CrossRef]

174. Bertin, M.; Nguyen, T.H.Y.; Bonvallot, N.; Bodin, J.; Roquelaure, Y. Occupational co-exposure to biomechanical factors and neurotoxic chemicals in a representative sample of French employees. J. Occup. Health 2020, 62, e12090. [CrossRef]

175. Hargreaves, S.; Rustage, K.; Nellums, L.B.; McAlpine, A.; Pocock, N.; Devakumar, D.; Aldridge, R.W.; Abubakar, I.; Kristensen, K.L.; Himmels, J.W.; et al. Occupational health outcomes among international migrant workers: A systematic review and meta-analysis. Lancet Glob. Health 2019, 7, E872-E882. [CrossRef]

176. Neitzel, R.L.; Krenz, J.; de Castro, A.B. Safety and Health Hazard Observations in Hmong Farming Operations. J. Agromed. 2014, 19, 130-149. [CrossRef]

177. Scribani, M.; Wyckoff, S.; Jenkins, P.; Bauer, H.; Earle-Richardson, G. Migrant and Seasonal Crop Worker Injury and Illness Across the Northeast. Am. J. Ind. Med. 2013, 56, 845-855. [CrossRef]

178. Kearney, G.D.; Allen, D.L.; Balanay, J.A.G.; Barry, P. A Descriptive Study of Body Pain and Work-Related Musculoskeletal Disorders Among Latino Farmworkers Working on Sweet Potato Farms in Eastern North Carolina. J. Agromed. 2016, 21, 234-243. [CrossRef] [PubMed]

179. Perla, M.E.; Iman, E.; Campos, L.; Perkins, A.; Liebman, A.K.; Miller, M.E.; Beaudet, N.J.; Karr, C.J. Agricultural Ocuppational Health and Safety Perspectives Among Latino-American Youth. J. Agromed. 2015, 20, 167-177. [CrossRef]

180. Callejón-Ferre, A.J.; Montoya-García, M.E.; Pérez-Alonso, J.; Rojas-Sola, J.I. The psychosocial risks of farm workers in south-east Spain. Saf. Sci. 2015, 78, 77-90. [CrossRef]

181. Montoya-García, M.E.; Callejón-Ferre, A.J.; Pérez-Alonso, J.; Sánchez-Hermosilla, J. Assessment of paychosocial risks faced by workers in Almería-type greenhouses, using the Mini Psychosocial Factor method. Appl. Ergon. 2013, 44, 303-311. [CrossRef] [PubMed]

182. Colindres, C.; Cohen, A.; Caxaj, C.S. Migrant agricultural workers' health, safety and access to protections: A descriptive survey identifying structural gaps and vulnerabilities in the interior of British Columbia, Canada. Int. J. Environ. Res. Public Health 2021, 18, 3696. [CrossRef]

183. Caffaro, F.; Bagagiolo, G.; Cremasco, M.M.; Cavallo, E. Participatory ergonomic design of a safety training tool for migrant workers in agriculture. Chem. Eng. Trans. 2017, 58, 25-30.

184. Saiyed, H.N.; Tiwari, R.R. Occupational health research in India. Ind. Health 2004, 42, 141-148. [CrossRef]

185. Hartman, E.; Vrielink, H.H.E.O.; Huirne, R.B.M.; Metz, J.H.M. Sick leave analysis among self-employed Dutch farmers. Occup. Med.-Oxf. 2003, 53, 461-468. [CrossRef] [PubMed]

186. Hildebrandt, V.H. Musculoskeletal symptoms and workload in 12 branches of Dutch agriculture. Ergonomics 1995, 38, 2576-2587. [CrossRef]

187. Hartman, E.; Vrielink, H.H.E.O.; Huirne, R.B.M.; Metz, J.H.M. Risk factors for sick leave due to musculoskeletal disorders among self-employed Dutch farmers: A case-control study. Am. J. Ind. Med. 2006, 49, 204-214. [CrossRef]

188. Occhipinti, E.; Colombini, D. From complexity to simplification: Contribution of the EPM Research Unit to producing a toolkit for risk assessment and management of biomechanical overload and WMSDs prevention. Med. Lav. 2011, 102, $174-192$.

189. Cividino, S.R.S.; Pergher, G.; Gubiani, R.; Moreschi, C.; Da Broi, U.; Vello, M.; Rinaldi, F. Definition of a Methodology for Gradual and Sustainable Safety Improvements on Farms and Its Preliminary Applications. Agriculture 2018, 8, 7. [CrossRef]

190. Min, D.; Baek, S.; Park, H.W.; Lee, S.A.; Moon, J.; Yang, J.E.; Kim, K.S.; Kim, Y.; Kang, E.K. Prevalence and Characteristics of Musculoskeletal Pain in Korean Farmers. Ann. Rehabil. Med. 2016, 40, 1-13. [CrossRef]

191. Fouquet, N.; Bodin, J.; Chazelle, E.; Descatha, A.; Roquelaure, Y. Use of Multiple Data Sources for Surveillance of Work-Related Chronic Low-Back Pain and Disc-Related Sciatica in a French Region. Ann. Work Expo. Health 2018, 62, 530-546. [CrossRef] [PubMed]

192. Zalk, D.M. Grassroots ergonomics: Initiating an ergonomics program utilizing participatory techniques. Ann. Occup. Hyg. 2001, 45, 283-289. [CrossRef]

193. Volkmer, K.; Molitor, W.L. Interventions Addressing Injury among Agricultural Workers: A Systematic Review. J. Agromed. 2019, 24, 26-34. [CrossRef] [PubMed]

194. Faucett, J.; Meyers, J.; Miles, J.; Janowitz, I.; Fathallah, F. Rest break interventions in stoop labor tasks. Appl. Ergon. 2007, 38, 219-226. [CrossRef] [PubMed]

195. Hildebrand, M.W.; Brinkley, J.; Timmons, S.; Mendez, F. What occupational and physical therapists know about farmers' health. J. Agromed. 2019, 24, 64-73. [CrossRef] [PubMed] 
196. McMillan, M.; Trask, C.; Dosman, J.; Hagel, L.; Pickett, W. Prevalence of musculoskeletal disorders among Saskatchewan farmers. J. Agromed. 2015, 20, 292-301. [CrossRef]

197. Luque, J.S.; Reyes-Ortiz, C.; Marella, P.; Bowers, A.; Panchal, V.; Anderson, L.; Charles, S. Mobile Farm Clinic Outreach to Address Health Conditions Among Latino Migrant Farmworkers in Georgia. J. Agromed. 2012, 17, 386-397. [CrossRef]

198. Alterman, T.; Steege, A.L.; Li, J.; Petersen, M.R.; Muntaner, C. Ethnic, racial, and gender variations in health among farm operators in the United States. Ann. Epidemiol. 2008, 18, 179-186. [CrossRef] [PubMed]

199. Mitchell, R.J.; Lystad, R.P. Occupational injury and disease in the Australian aquaculture industry. Mar. Policy 2019, 99, $216-222$. [CrossRef]

200. Lee, S.J.; Tak, S.; Alterman, T.; Calvert, G.M. Prevalence of Musculoskeletal Symptoms Among Agricultural Workers in the United States: An Analysis of the National Health Interview Survey, 2004-2008. J. Agromed. 2014, 19, 268-280. [CrossRef] [PubMed]

201. Pingle, S. Occupational Safety and Health in India: Now and the Future. Ind. Health 2012, 50, 167-171. [CrossRef]

202. Mas, F.S.; Handal, A.J.; Rohrer, R.E.; Viteri, E.T. Health and Safety in Organic Farming: A Qualitative Study. J. Agromed. 2018, 23, 92-104.

203. Dos Reis, M.M.; de Oliveira, A.P.N.; Turci, S.R.B.; Dantas, R.M.; da Silva, V.D.P.; Gross, C.; Jensen, T.; Silva, V.L.D.C.E. Knowledge, attitudes, and practices of women farmers concerning tobacco agriculture in a municipality in Southern Brazil. Cad. Saude Publica 2017, 33, e00080516. [CrossRef]

204. Jain, R.; Sain, M.K.; Meena, M.L.; Dangayach, G.S.; Bhardwaj, A.K. Non-powered hand tool improvement research for prevention of work-related problems: A review. Int. J. Occup. Saf. Ergon. 2018, 24, 347-357. [CrossRef]

205. Chapman, L.J.; Newenhouse, A.C.; Pereira, K.M.; Karsh, B.T.; Meyer, R.M.; Brunette, C.M.; Ehlers, J.J. Evaluation of a four-year intervention to reduce musculoskeletal hazards among berry growers. J. Saf. Res. 2008, 39, 215-224. [CrossRef]

206. Chapman, L.J.; Newenhouse, A.C.; Karsh, B.T. Evaluation of a 3-year intervention to increase adoption of safer nursery crop production practices. Appl. Ergon. 2010, 41, 18-26. [CrossRef]

207. Chapman, L.J.; Brunette, C.M.; Karsh, B.T.; Taveira, A.D.; Josefsson, K.G. A 4-Year Intervention to Increase Adoption of Safer Dairy Farming Work Practices. Int. J. Ind. Ergon. 2011, 54, 232-243. [CrossRef]

208. Riemer, R.; Bechar, A. Investigation of productivity enhancement and biomechanical risks in greenhouse crops. Biosyst. Eng. 2016, 147, 39-50. [CrossRef]

209. Jo, H.; Baek, S.; Park, H.W.; Lee, S.A.; Moon, J.; Yang, J.E.; Kim, K.S.; Kim, J.Y.; Kang, E.K. Farmers' Cohort for Agricultural Work-Related Musculoskeletal Disorders (FARM) Study: Study Design, Methods, and Baseline Characteristics of Enrolled Subjects. J. Epidemiol. 2016, 26, 50-56. [CrossRef]

210. Kishtwaria, J.; Rana, A. Ergonomic interventions in weeding operations for drudgery reduction of hill farm women of India. Work 2012, 41, 4349-4355. [CrossRef] [PubMed]

211. García-Cáceres, R.G.; Felknor, S.; Cordoba, J.E.; Caballero, J.P.; Barrero, L.H. Hand anthropometry of the Colombian floriculture workers of the Bogota plateau. Int. J. Ind. Ergon. 2012, 42, 183-198. [CrossRef]

212. Kishtwaria, J.; Rana, A. Intervention of gender friendly land preparation technologies for drudgery reduction of hill farm women. Work 2012, 41, 4342-4348. [CrossRef] [PubMed]

213. Sari, A.D.; Pusfitasari, N.; Rahma, R. Design and Evaluation New Rice Planter Tool without Mechanical Engine for Improving Conventional Farmer's Posture as Revival of Agriculture's Indonesia. Curr. Trends Ergon. 2013, 10, 116.

214. Aida, T.; Nozaki, H.; Kobayashi, H. Development of Muscle Suit and Application to Factory Laborers. In Proceedings of the IEEE International Conference on Mechatronics and Automation, Changchum, China, 9-12 August 2009.

215. Milosavljevic, S.; Bagheri, N.; Vasiljev, R.M.; Mcbride, D.I.; Rehn, B. Does Daily Exposure to Whole-Body Vibration and Mechanical Shock Relate to the Prevalence of Low Back and Neck Pain in a Rural Workforce? Ann. Occup. Hyg. 2012, 56, 10-17. [PubMed]

216. Clay, L.; Milosavljevic, S.; Trask, C. Predicting Whole Body Vibration Exposure from Occupational Quad Bike Use in Farmers. Safety 2015, 1, 71-83. [CrossRef]

217. Yung, M.; Lang, A.E.; Stobart, J.; Kociolek, A.M.; Milosavljevic, S.; Trask, C. The combined fatigue effects of sequential exposure to seated whole body vibration and physical, mental, or concurrent work demands. PLoS ONE 2017, 12, e0188468. [CrossRef]

218. Butkus, R.; Vasiliauskas, G. Farmers' exposure to noise and vibration in small and médium-sized farms. In Proceedings of the 8th International Scientific Conference on Rural Development-Bioeconomy Challenges, Aleksandras Stulginskis Universitetas, Akademija, Lithuania, 23-24 November 2017.

219. Thamsuwan, O.; Galvin, K.; Tchong-French, M.; Aulck, L.; Boyle, L.N.; Ching, R.P.; McQuade, K.J.; Johnson, P.W. Comparisons of physical exposure between workers harvesting apples on mobile orchard platforms and ladders, part 2: Repetitive upper arm motions. Appl. Ergon. 2020, 89, 103192. [CrossRef] [PubMed]

220. Benos, L.; Tsaopoulos, D.; Bochtis, D. A Review on Ergonomics in Agriculture. Part II: Mechanized Operations. Appl. Sci. 2020, 10, 3484. [CrossRef]

221. Gumasing, M.J.J.; Robielos, R.A.C. Ergonomic Intervention Addressing Musculoskeletal Disorders among Poultry Layer Workers. In Proceedings of the 5th International Conference on Industrial Engineering and Applications (ICIEA), National University Singapore, Shaw Fdn Alumni House, Singapore, 26-28 April 2018.

222. Stal, M.; Pinzke, S.; Hansson, G.A. The effect on workload by using a support arm in parlour milking. Int. J. Ind. Ergon. 2003, 32, 121-132. [CrossRef] 
223. Karttunen, J.P.; Rautiainen, R.H.; Lunner-Kolstrup, C. Occupational Health and Safety of Finnish Dairy Farmers Using Automatic Milking Systems. Front. Public Health 2016, 4, 147. [CrossRef] [PubMed]

224. Pistolesi, F.; Lazzerini, B. Assessing the Risk of Low Back Pain and Injury via Inertial and Barometric Sensors. IEEE Trans. Ind. Inf. 2020, 16, 7199-7208. [CrossRef]

225. Fethke, N.B.; Schall, M.C.; Chen, H.W.; Branch, C.A.; Merlino, L.A. Biomechanical factors during common agricultural activities: Results of on-farm exposure assessments using direct measurement methods. J. Occup. Envireon. Hyg. 2020, 17, 85-96. [CrossRef] [PubMed]

226. Mokdad, M.; Bouhafs, M.; Lahcene, B.; Mokdad, I. Ergonomic practices in Africa: Date palm work in Algeria as an example. Work 2019, 62, 657-665. [CrossRef]

227. Merino, G.; da Silva, L.; Mattos, D.; Guimaraes, B.; Merino, E. Ergonomic evaluation of the musculoskeletal risks in a banana harvesting activity through qualitative and quantitative measures, with emphasis on motion capture (Xsens) and EMG. Int. J. Ind. Ergon. 2019, 69, 80-89. [CrossRef]

228. Quandt, S.A.; Kucera, K.L.; Haynes, C.; Klein, B.G.; Langley, R.; Agnew, M.; Levin, J.L.; Howard, T.; Nussbaum, M.A. Occupational Health Outcomes for Workers in the Agriculture, Forestry and Fishing Sector: Implications for Immigrant Workers in the Southeastern US. Am. J. Ind. Med. 2013, 56, 940-959. [CrossRef]

229. Buranatrevedh, S.; Sweatsriskul, P. Model development for health promotion and control of agricultural occupational health hazards and accidents in Pathumthani, Thailand. Ind. Health 2005, 43, 669-676. [CrossRef]

230. Donham, K.J.; Larabee, B. The Changing Face of Agricultural Health and Safety-Alternative Agriculture. J. Agromed. 2009, 14, 70-75. [CrossRef] [PubMed]

231. Tavolaro, P.; Pereira, I.M.T.B.; Pelicioni, M.C.F.; de Oliveira, C.A.F. Empowerment as a way to prevent work-related health conditions in slaughterhouse workers. Rev. Saude Publ. 2007, 41, 307-312. [CrossRef] [PubMed]

232. Barrero, L.H.; Ceballos, C.; Ellegast, R.; Pulido, J.A.; Monroy, M.A.; Berrio, S.; Quintana, L.A. A randomized intervention trial to reduce mechanical exposures in the Colombian flower industry. Work 2012, 41, 4971-4974. [CrossRef] [PubMed]

233. Sejari, N.; Kamaruddin, K.; Al-Worafi, Y.M.A.; Ming, L.C. A narrative review of massage and spinal manipulation in the treatment of low back pain. Arch. Pharm. Pract. 2014, 5, 139-143.

234. Barrero, L.H.; Ceballos, C.; Ellegast, R.; Pulido, J.A.; Monroy, M.A.; Berrio, S.; Quintana, L.A. A randomized intervention trial to reduce mechanical exposures in the Colombian flower industry. Work 2014, 49, 51-62. [CrossRef] [PubMed]

235. Velasquez, S.; Valderrama, S.; Giraldo, D. Ergonomic assessment of natural rubber processing in plantations and small enterprises. Ing. Compet. 2016, 18, 233-246.

236. Houshyar, E.; Kim, I.J. Understanding musculoskeletal disorders among Iranian apple harvesting laborers: Ergonomic and stopwatch time studies. Int. J. Ind. Ergon. 2018, 67, 32-40. [CrossRef]

237. Tewtow, S.; Bhuanantanondh, P.; Mekhora, K. Prevalence of Work-Related Musculoskeletal Disorders among Thai Oil Palm Workers in Khao Phanom District, Krabi Province, Thailand. Ind. Eng. Manag. Syst. 2019, 18, 630-637. [CrossRef]

238. Mishra, D.; Satapathy, S. Intelligent Decision-Making Approaches for Agricultural Sectors of Odisha in India. Int. J. Decis. Support. Syst. Technol. 2019, 11, 67-95. [CrossRef]

239. Arabian, A.; Omidi, L.; Bakhshi, E.; Ghanbari, A.; Torabinassaj, E.; Zakerian, S.A. Assessment of occupational safety, health, and ergonomics issues in agriculture in some cities of Iran. Work 2020, 65, 89-96. [CrossRef]

240. Nevala-Puranen, N. Effects of occupationally-oriented rehabilitation on farmers' work techniques, musculoskeletal symptoms, and work ability. J. Occup. Rehabil. 1996, 6, 191-200. [CrossRef] [PubMed]

241. Meyers, J.M.; Miles, J.A.; Faucett, J.; Janowitz, I.; Tejeda, D.G.; Kabashima, J.N. Ergonomics in agriculture: Workplace priority setting in the nursery industry. Am. Ind. Hyg. Assoc. J. 1997, 58, 121-126. [CrossRef]

242. Chapman, L.J.; Newenhouse, A.C.; Meyer, R.H.; Taveira, A.D.; Karsh, B.T.; Ehlers, J.J.; Palermo, T. Evaluation of an intervention to reduce musculoskeletal hazards among fresh market vegetable growers. Appl. Ergon. 2004, 35, 57-66. [CrossRef]

243. Hartman, E.; Vrielink, H.H.E.O.; Huirne, R.B.M.; Metz, J.H.M. Exposure to physical risk factors in Dutch agriculture: Effect on sick leave due to musculoskeletal disorders. Int. J. Ind. Ergon. 2005, 35, 1031-1045. [CrossRef]

244. Earle-Richardson, G.; Jenkins, P.L.; Freivalds, A.; Burdick, P.; Park, S.; Lee, C.; Mason, C.; May, J.J. Laboratory evaluation of belt usage with apple buckets. Am. J. Ind. Med. 2006, 49, 23-29. [CrossRef] [PubMed]

245. Fuchs, A.; Kouimintzis, D.; Neumann, G.; Kirch, W. Health risks related to crop farming in Europe. Z. Gesundh Wiss 2007, 15, 233-244. [CrossRef]

246. Fenske, R.A. New Technologies and Worker Safety in Western Agriculture. J. Agromed. 2009, 14, 417-420. [CrossRef]

247. Kirkhorn, S.R.; Earle-Richardson, G.; Banks, R.J. Ergonomic Risks and Musculoskeletal Disorders in Production Agriculture: Recommendations for Effective Research to Practice. J. Agromed. 2010, 15, 281-299. [CrossRef] [PubMed]

248. Kee, D.; Chung, M.K.; Kim, J.H. Legal system and its effect for prevention of work-related musculoskeletal disorders in Korea. Int. J. Ind. Ergon. 2011, 41, 224-232. [CrossRef]

249. Hermans, V.; O’Neill, D.; Motmans, R.; Lundqvist, P.; Roman-Liu, D. Social partners cooperation for reduction of musculoskeletal disorders in agriculture. Work 2012, 41, 5327-5333. [CrossRef]

250. Calvert, G.M.; Lee, K.; Roh, S.; Davis, K.G.; Tak, S. Promoting and Protecting Worker Health and Safety in the Republic of Korea Agricultural Sector. J. Agromed. 2012, 17, 326-337. [CrossRef] [PubMed] 
251. Calderon, M. Health and safety on small fishing vessels. In Proceedings of the 8th International Symposium on Occupational Safety and Hygiene (SHO), University of Minho, Guimaraes, Portugal, 9-10 February 2012.

252. Karttunen, J.P.; Rautiainen, R.H. Distribution and Characteristics of Occupational Injuries and Diseases Among Farmers: A Retrospective Analysis of Workers' Compensation Claims. Am. J. Ind. Med. 2013, 56, 856-869. [CrossRef] [PubMed]

253. Karttunen, J.P.; Rautiainen, R.H. Characteristics of and Risk Factors for Compensated Occupational Injury and Disease Claims in Dairy Farmers: A Case-Control Study. J. Agric. Saf. Health 2013, 19, 191-206.

254. Chapman, L.J.; Brunette, C.M.; Taveira, A.D. A Seven-Year Intervention to Diffuse Economic Innovations with Safety Benefits to Wisconsin Dairy Farmers. J. Agric. Saf. Health 2013, 19, 147-162.

255. Hudson, D.S.; Copeland, J.L.; Hepburn, C.G.; Doan, J.B. Stooped Postures Are Modified by Pretask Walking in a Simulated Weed-Pulling Task. J. Agromed. 2014, 19, 27-34. [CrossRef]

256. Fathallah, F.A.; Tang, S.C.H.; Waters, T. Development and Evaluation of Ergonomic Interventions for Bucket Handling on Farms. Hum. Factors 2016, 58, 758-776. [CrossRef]

257. Occhipinti, E.; Colombini, D. A toolkit for the analysis of biomechanical overload and prevention of WMSDs: Criteria, procedures and tool selection in a step-by-step approach. Int. J. Ind. Ergon. 2016, 52, 18-28. [CrossRef]

258. Pinzke, S.; Lavesson, L. Ergonomic conditions in manual harvesting in Swedish outdoor cultivation. Ann. Agric. Environ. Med. 2018, 25, 481-487. [CrossRef]

259. Gómez-Galán, M.; Pérez-Alonso, J.; Callejón-Ferre, A.J.; Sánchez-Hermosilla-López, J. Assessment of Postural Load during Melon Cultivation in Mediterranean Greenhouses. Sustainability 2018, 10, 2729. [CrossRef]

260. Yung, M.; Tennant, L.M.; Milosavljevic, S.; Trask, C. The Multisystem Effects of Simulated Agricultural Whole Body Vibration on Acute Sensorimotor, Physical, and Cognitive Performance. Ann. Work Expo. Health 2018, 62, 884-898.

261. Garrison, E.B.; Dropkin, J.; Russell, R.; Jenkins, P. Modified PATH Methodology for Obtaining Interval-Scaled Postural Assessments of Farmworkers. J. Agric. Saf. Health 2018, 24, 43-52. [CrossRef]

262. Fethke, N.B.; Schall, M.C.; Merlino, L.A.; Chen, H.; Branch, C.A.; Ramaswamy, M. Whole-Body Vibration and Trunk Posture During Operation of Agricultural Machinery. Ann. Work Expo. Health 2018, 62, 1123-1133. [CrossRef] [PubMed]

263. Calvo, A.; Romano, E.; Preti, C.; Schillaci, G.; Deboli, R. Upper limb disorders and hand-arm vibration risks with hand-held olive beaters. Int. J. Ind. Ergon. 2018, 65, 36-45. [CrossRef]

264. Maric, A.; Pavlovic, T. Conditions and possibilities of geothermal energy utilization for economic-touristic development. J. Geogr. Inst. Cvijic 2018, 68, 233-248. [CrossRef]

265. Missikpode, C.; Peek-Asa, C.; Wright, B.; Ramirez, M. Characteristics of agricultural and occupational injuries by workers' compensation and other payer sources. Am. J. Ind. Med. 2019, 62, 969-977. [CrossRef]

266. Kee, D.; Haslam, R. Prevalence of work-related musculoskeletal disorders in agriculture workers in Korea and preventative interventions. Work 2019, 64, 763-775. [CrossRef] [PubMed]

267. Bath, B.; Jaindl, B.; Dykes, L.; Coulthard, J.; Naylen, J.; Rocheleau, N.; Clay, L.; Khan, M.I.; Trask, C. Get 'Er Done: Experiences of Canadian Farmers Living with Chronic Low Back Disorders. Physiother. Can. 2019, 71, 24-33. [CrossRef] [PubMed]

268. Zorrilla-Muñoz, V.; Agullo-Tomas, M.S.; Garcia-Sedano, T. Socio-ergonomic analysis in agriculture. Evaluation of the oleic sector from a gender and aging perspective. ITEA-Inf. Technol. Econ. Agric. 2019, 115, 83-104.

269. Khan, M.I.; Bath, B.; Boden, C.; Adebayo, O.; Trask, C. The association between awkward working posture and low back disorders in farmers: A systematic review. J. Agromed. 2019, 24, 74-89. [CrossRef]

270. Gómez-Galán, M.; González-Parra, J.M.; Pérez-Alonso, J.; Golasi, I.; Callejón-Ferre, A.J. Forced Postures in Courgette Greenhouse Workers. Agronomy 2019, 9, 253. [CrossRef]

271. Romano, E.; Pirozzi, M.; Ferri, M.; Calcante, A.; Oberti, R.; Vitale, E.; Rapisarda, V. The use of pressure mapping to assess the comfort of agricultural machinery seats. Int. J. Ind. Ergon. 2020, 77, 102835. [CrossRef]

272. Imeah, B.; Penz, E.; Rana, M.; Trask, C. Economic analysis of new workplace technology including productivity and injury: The case of needle-less injection in swine. PLOS ONE 2020, 15, e0233599. [CrossRef]

273. Van der Molen, H.F.; Marsili, C.; Vitali, A.; Colosio, C. Trends in occupational diseases in the Italian agricultural sector, $2004-2017$. Occup. Environ. Med. 2020, 77, 340-343. [CrossRef]

274. Gómez-Galán, M.; Callejón-Ferre, A.J.; Díaz-Pérez, M.; Carreño-Ortega, A.; López-Martínez, A. Risk of musculoskeletal disorders in pepper cultivation workers. EXCLI J. 2021, 20, 1033-1054. [PubMed]

275. United Nations (UN). Member States. Available online: https://www.un.org/en/about-us/member-states (accessed on 7 July 2021).

276. Lee, H.Y.; Yeh, W.Y.; Chen, C.W.; Wang, J.D. Prevalence and psychosocial risk factors of upper extremity musculoskeletal pain in industries of Taiwan: A nationwide study. J. Occup. Health 2005, 47, 311-318. [CrossRef]

277. Karttunen, J.P.; Rautiainen, R.H.; Leppala, J. Characteristics and Costs of Disability Pensions in Finnish Agriculture Based on 5-Year Insurance Records. J. Agromed. 2015, 20, 282-291. [CrossRef] [PubMed]

278. Ropponen, A.; Samuelsson, A.; Alexanderson, K.; Svedberg, P. Register-based data of psychosocial working conditions and occupational groups as predictors of disability pension due to musculoskeletal diagnoses: A prospective cohort study of 24.543 Swedish twins. BMC Musculoskelet. Dis. 2013, 14, 268. [CrossRef]

279. Smith, P.M.; Black, O.; Keegel, T.; Collie, A. Are the Predictors of Work Absence Following a Work-Related Injury Similar for Musculoskeletal and Mental Health Claims? J. Occup. Rehabil. 2014, 24, 79-88. [CrossRef] 
280. Thelin, A.; Holmberg, S.; Thelin, N. Functioning in neck and low back pain from a 12-year perspective: A prospective populationbased study. J. Rehabil. Med. 2008, 40, 555-561. [CrossRef]

281. Callejón-Ferre, A.J.; Pérez-Alonso, J.; Sánchez-Hermosilla, J.; Carreño-Ortega, A. Ergonomics and psycho-sociological quality indeces in greenhouses, Almeria (Spain). Span. J. Agric. Res. 2009, 7, 50-58. [CrossRef]

282. Choina, P.; Solecki, L.; Gozdziewska, M.; Buczaj, A. Assessment of musculoskeletal system pain complaints reported by forestry workers. Ann. Agric. Environ. Med. 2018, 25, 338-344. [CrossRef] [PubMed] 